\title{
DAMPAK ZAKAT, INFAK DAN SEDEKAH (ZIS) TERHADAP PENURUNAN TINGKAT KEMISKINAN DAN PERCEPATAN PENGENTASAN KEMISK DAMPAK ZAKAT, INFAK DAN SEDEKAHINAN
}

(Studi Kasus LAZDAI dan DPU-DT di Bandar Lampung)

\begin{tabular}{|c|c|c|}
\hline \multicolumn{3}{|c|}{ P-ISSN: 2085-4536 | E-ISSN: 2721-7183 } \\
\hline \multicolumn{3}{|c|}{ Link: https://jurnal-stidnatsir.ac.id/index.php/binaummat/article/view/40 } \\
\hline \multicolumn{3}{|c|}{ DOI : $\underline{\text { https://doi.org/10.38214/jurnalbinaummatstidnatsir.v2i01.40 }}$} \\
\hline Dikirim: 25-03-2019 & Direview: 05-04-2019 & Diterbitkan: 17-04-2019 \\
\hline \multicolumn{3}{|c|}{$\begin{array}{c}\text { AMIN NUR KHOLID } \\
\text { STID Mohammad Natsir, Indonesia } \\
\text { aminnurkholid@stidnatsir.ac.id }\end{array}$} \\
\hline
\end{tabular}

\begin{abstract}
ABSTRAK
Tujuan Penelitian: Untuk menganalisa dampak pendistribusian ZIS dalam mereduksi tingkat kemiskinan dan mempercepat proses pengentasan kemiskinan dengan mengambil studi kasus Lembaga Amil Zakat Daerah Amal Insani (LAZDAI) dan DPU-DT Lampung. Metode Penelitian: Penelitian ini menggunakan pendekatan kualitatif. Data yang digunakan adalah data tahun 2011. Penelitian ini menggunakan dua jenis data, yaitu data primer dan data sekunder. Data primer diperoleh dari wawancara langsung kepada 186 reponden (mustahik). Sedangkan data sekunder berupa garis kemiskinan berdasarkan nishab emas dan literature pendukung. Penelitian ini menggunakan sejumlah alat analisa, yaitu T-Statistik untuk mengetahui apakah distribusi ZIS berpengaruh nyata terhadap pendapatan mustahik atau tidak, Headcount Ratio $(\mathrm{H})$ untuk mengetahui insiden kemiskinan (poverty incidence), Poverty Gap Ratio (P1) dan Income Index (I) untuk mengukur tingkat kedalaman kemiskinan, dan Sen Index of Poverty (P2) serta FGT Index (P3) untuk mengukur tingkat keparahan kemiskinan. Sedangkan formula Time Taken to Exit digunakan untuk menganalisa waktu yang dibutuhkan untuk mengentaskan kemiskinan rumah tangga mustahik. Hasil penelitian: Pada taraf nyata 5 persen, distribusi ZIS berpengaruh secara signifikan dan positif terhadap pendapatan keluarga mustahik. Distribusi ZIS mampu mereduksi jumlah kemiskinan (poverty incidence), kedalaman kemiskinan (poverty gap dan income index), dan keparahan kemiskinan (poverty severity index). Hasil penelitian juga menunjukkan bahwa ZIS mampu mempersingkat/mempercepat waktu pengentasan kemiskinan.
\end{abstract}

Kata kunci: dampak, zakat, infaq, sedekah, kemiskinan 


\section{PENDAHULUAN}

Di antara persoalan besar yang dihadapi bangsa Indonesia hingga saat ini adalah persoalan kemiskinan dan ketimpangan pendapatan antar kelompok masyarakat. Terlepas dari komitmen pemerintah yang semakin tinggi dalam pengentasan kemiskinan, angka kemiskinan masih berada di level yang tinggi dan tingkat ketimpangan pendapatan antar kelompok masyarakat semakin meningkat.

Pasca krisis 1997, strategi pengentasan kemiskinan dan pengangguran berbasis pertumbuhan ekonomi, tidak efektif. ${ }^{1}$ Tingkat pertumbuhan yang meyakinkan dan semakin tinggi, terbukti belum mampu mengurangi angka kemiskinan secara signifikan. Selain itu, pertumbuhan ekonomi juga belum mampu memperbaiki distribusi pendapatan antar kelompok masyarakat. Tabel 1.1 berikut menggambarkan tingkat pertumbuhan ekonomi, jumlah penduduk miskin, prosentase penduduk miskin, dan rasio gini periode 2005-2011.

Tabel 1.1. Jumlah Penduduk Miskin, Prosentase Penduduk Miskin, Tingkat

Pertumbuhan Ekonomi dan Gini Rasio 2005-2011.

\begin{tabular}{|c|c|c|c|c|c|}
\hline $\begin{array}{c}\mathrm{N} \\
\mathrm{o}\end{array}$ & Tahun & $\begin{array}{c}\text { Pertumbuhan } \\
\text { Ekonomi (\%) }\end{array}$ & $\begin{array}{c}\text { Jumlah Penduduk } \\
\text { Miskin (Juta) }\end{array}$ & $\begin{array}{c}\text { \% Terhadap } \\
\text { Total Populasi }\end{array}$ & Gini Rasio \\
\hline 1 & 2005 & 5,6 & 35,10 & 15,97 & 0,34 \\
\hline 2 & 2006 & 6,1 & 39,30 & 17,75 & 0,36 \\
\hline 3 & 2007 & 6,3 & 37,17 & 16,58 & 0,38 \\
\hline 4 & 2008 & 6,1 & 34,96 & 15,42 & 0,37 \\
\hline 5 & 2009 & 4,5 & 32,53 & 14,15 & 0,37 \\
\hline 6 & 2010 & 6,1 & 31,02 & 13,33 & 0,38 \\
\hline 7 & 2011 & 6,5 & 30,02 & 12,49 & 0,43 \\
\hline
\end{tabular}

Sumber: BPS. ${ }^{2}$

Secara umum, sebagaimana yang dipaparkan pada tabel 1.1, angka kemiskinan dalam kurun waktu 2005- Maret 2011 turun sebesar 5,08 juta jiwa, yaitu 35,10 juta jiwa pada tahun 2005 menjadi 30,02 juta jiwa pada Maret 2011.

${ }^{1}$ IZDR 2010, Menggagas Arsitektur Zakat Indonesia:Menuju Sinergi Pemerintah dan Masyarakat Sipil dalam Pengelolaan Zakat Nasional,Ciputat: IMZ, Cet. II 2011, hal. 3.

${ }^{2}$ Analisis dan Penghitungan Tingkat Kemiskinan 2011, Jakarta: BPS 2011, hal. 44-54 (Soft Copy), dan Berita Resmi Statistik: Pertumbuhan Ekonomi Indonesia Tahun 2005-2011, BPS. 
Sementara prosentase penduduk miskin terhadap total populasi turun sebesar 3,48 persen, yaitu dari 15,97 persen menjadi 12,49 persen pada periode yang sama. Hal ini menegaskan rendahnya prosentase penurunan tingkat kemiskinan selama 6 tahun.

Meskipun trennya terjadi penurunan, tapi jumlah penduduk miskin yang mencapai lebih 30 juta jiwa ini masih tergolong cukup besar mengingat sumber daya alam kita yang melimpah. Selain itu, angka tersebut hanya menghitung warga yang pengeluarannya di bawah garis kemiskinan Rp 233.740,- per kapita perbulan (GK Maret 2011), bukan warga miskin yang pengeluarannya hanya sedikit di atas garis kemiskinan. Menurut khudhori, ${ }^{3}$ jika golongan terakhir ini dihitung, jumlahnya bisa mencapai 70 juta (seperti penerima raskin) atau 76,4 juta (penerima jamkesmas).

Sementara itu, berdasarkan rasio gini, ketimpangan pendapatan antar kelompok masyarakat ternyata mengalami peningkatan dari 0,34 pada 2005 menjadi 0,43 pada Maret 2011. Kondisi ini mengindikasikan kue pertumbuhan ekonomi yang dinikmati kelompok menengah ke atas, jauh lebih besar bila dibandingkan dengan kue pertumbuhan ekonomi yang dinikmati oleh kelompok menengah ke bawah. Meskipun ketimpangan pendapatan pada 2011 masuk kategori sedang versi bank dunia, namun hal ini patut menjadi perhatian serius karena apabila rasio gini mencapai angka 0,5 maka ketimpangan pendapatan sudah masuk katagori buruk (tinggi). Kesenjangan ekonomi yang tinggi akan memicu masalah sosial jika tidak segera diatasi.

Hal yang sama juga terlihat dengan kriteria pengukuran ketimpangan dari Bank Dunia. Kriteria Bank Dunia ${ }^{4}$ membagi kelompok penduduk menjadi tiga bagian besar, yaitu $40 \%$ penduduk berpendapatan terendah, $40 \%$ berpendapatan menengah, dan $20 \%$ berpendapatan tertinggi. Berdasarkan kriteria tersebut, pada tabel 1.2 ditunjukkan bahwa share pertumbuhan ekonomi yang dinikmati oleh $40 \%$ penduduk berpenghasilan terendah terus mengalami penurunan, dari $21,84 \%$ pada tahun 2005 menjadi $16,86 \%$ pada tahun 2011. Sementara itu, share pertumbuhan ekonomi yang dinikmati $20 \%$ penduduk berpenghasilan tertinggi mengalami peningkatan, dari 40,43\% pada tahun 2005 menjadi 48,41\% pada tahun 2011.

Tabel 1.2. Ketimpangan Distribusi Pendapatan 2005 - 2011 (Kriteria Bank Dunia)

\begin{tabular}{|c|c|c|c|c|}
\hline $\begin{array}{l}\mathrm{N} \\
\mathrm{O}\end{array}$ & Tahun & $\begin{array}{l}40 \% \text { berpendapatan } \\
\text { terendah }\end{array}$ & $\begin{array}{l}40 \% \text { berpendapatan } \\
\text { menengah }\end{array}$ & $\begin{array}{c}20 \% \text { berpendapatan } \\
\text { tertinggi }\end{array}$ \\
\hline
\end{tabular}

${ }^{3}$ Khudori, Gagal Atasi Kemiskinan, Republika, Kamis, 13 Januari 2011, hal. 2 .

${ }^{4}$ Analisis dan Penghitungan Tingkat Kemiskinan 2011, Jakarta: BPS 2011, hal. 58-60 (Soft Copy). 


\begin{tabular}{|l|l|l|l|l|}
\hline 1 & 2005 & 21,84 & 37,73 & 40,43 \\
\hline 2 & 2006 & 21,42 & 37,65 & 41,26 \\
\hline 3 & 2007 & 18,74 & 36,51 & 44,75 \\
\hline 4 & 2008 & 18,72 & 36,43 & 44,86 \\
\hline 5 & 2009 & 18,96 & 36,14 & 44,90 \\
\hline 6 & 2010 & 19,88 & 37,97 & 42,15 \\
\hline 7 & 2011 & 16,86 & 34,73 & 48,41 \\
\hline
\end{tabular}

Sumber: BPS. ${ }^{5}$

Memang tidak mudah mengentaskan kemiskinan. Apalagi kemiskinan merupakan bagian dari mata rantai lingkaran yang saling mempengaruhi. Inilah yang disebut dengan lingkaran setan kemiskinan atau perangkap kemiskinan (vicious cirle of poverty). Menurut Jhingan, ${ }^{6}$ lingkaran setan kemiskinan yang dikenalkan oleh Nurkse ini mengandung arti deretan melingkar kekuatankekuatan yang satu sama lain bereaksi sedemikian rupa sehingga menempatkan seseorang atau masyarakat suatu negara tetap berada dalam keadaan melarat. Lingkaran setan kemiskinan pada pokoknya berasal dari rendahnya produktivitas sebagai akibat kurangnya ketersediaan modal.

Secara umum, teori lingkaran setan kemiskinan dapat dijelaskan sebagai berikut: $^{7}$ produktivitas yang rendah akan menyebabkan rendahnya tingkat pendapatan. Tingkat pendapatan yang rendah menyebabkan tabungan yang rendah, sehingga investasi pun rendah. Tingkat investasi yang rendah menyebabkan kurangnya modal. Kurangnya modal kembali menyebabkan rendahnya produktivitas. Bagaimana mungkin masyarakat akan memiliki tingkat pendapatan tinggi jika produktivitasnya rendah. Lingkaran ini dilukiskan pada gambar 1.1

Gambar 1.1. Lingkaran Setan Kemiskinan

${ }^{5}$ Ibid, hal.59.

${ }^{6}$ Jhingan, Ekonomi Pembangunan dan Perencanaan, Jakarta: PT. Raja Grafindo Persada, Cet. VI, 1996, hal.42-43.

${ }^{7}$ Ibid, hal.43 


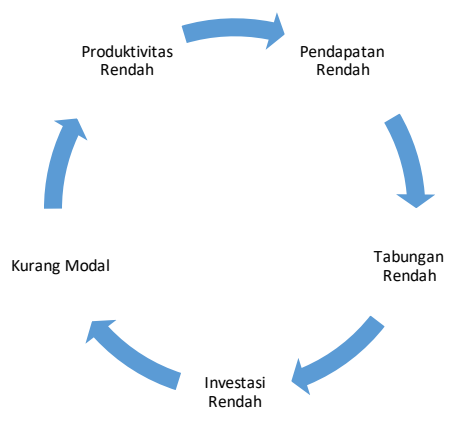

Sumber: Jhingan. ${ }^{8}$

Rendahnya prosentase penurunan kemiskinan dan meningkatnya ketimpangan pendapatan menegaskan perlunya revitalisasi strategi penanggulangan kemiskinan yang lebih komprehensif. Untuk itu, pemanfaatan instrumen yang memiliki potensi besar dalam mereduksi angka kemiskinan sangat dibutuhkan. Diantaranya adalah melalui zakat, infak dan sedekah (ZIS), yang merupakan salah satu pilar penting dalam perekonomian Islam setelah sektor riil (bisnis,perdagangan) dan sektor keuangan (moneter).

Zakat, infak dan sedekah (ZIS) dapat menjadi instrumen pengentasan kemiskinan yang tepat dan efektif. Hal tersebut didasarkan pada kenyataan bahwa mayoritas rakyat indonesia adalah beragama Islam. Potensi zakat berdasarkan riset Baznas dan Fakultas Ekonomi Manajemen (FEM) IPB tahun 20119 mencapai angka 3,4 persen dari total Produk Domestik Bruto (PDB) atau tidak kurang dari Rp 217 triliun setiap tahunnya. Potensi zakat yang sangat besar ini, menurut Beik dan Tsani (2012), ${ }^{10}$ harus dapat dioptimalkan dalam upaya pengentasan kemiskinan. Apalagi secara peruntukkannya, al-Quran memprioritaskan penyaluran zakat pada 8 kelompok, di mana fakir miskin menjadi kelompok yang mendapat prioritas utama. Jadi dengan demikian, keberadaan zakat dan ditambah dengan infak serta sedekah akan sangat membantu program pemerintah dalam mengentaskan kemiskinan. Sehingga tujuan pemerintah untuk mengentaskan kemiskinan diharapkan dapat terakselerasi dengan baik.

Oleh karena itu, pengembangan zakat, infak dan sedekah (ZIS) menjadi sebuah kebutuhan yang tidak dapat ditawar-tawar lagi. Integrasi ZIS dalam

\footnotetext{
${ }^{8}$ Jhingan, Ekonomi Pembangunan dan Perencanaan, hal. 43.

${ }^{9} \mathrm{http}: / /$ www.baznas.or.id/ib-peduli/ (diakses pd 17-09-2012, pkl.09.27.WIB).

${ }^{10}$ Beik,Irfan Syauqi dan Tsani,Tiara dalam "Menurunkan Kemiskinan Melalui Pendayagunaan Zakat." Jurnal Iqtishodia, Republika, Kamis, 23 Februari 2012, hal.23.
} 
kebijakan pembangunan nasional diharapkan dapat memperkuat upaya pemerintah dalam mengentaskan kemiskinan dan kesenjangan pendapatan. ${ }^{11}$

Salah satu wilayah yang memiliki tingkat kemiskinan tinggi adalah Propinsi Lampung yang basis utama perekonomiannya adalah pertanian. Berdasarkan data BPS per Maret 2011, ${ }^{12}$ Propinsi Lampung merupakan propinsi dengan jumlah penduduk terbesar ke lima di Indonesia dan ke dua di pulau Sumatera yaitu sebesar 1,30 juta jiwa atau 16,93 persen dari total populasi. Salah satu wilayah di Propinsi Lampung yang memiliki tingkat kemiskinan tinggi adalah kota Bandar lampung. Berdasarkan data BPS, ${ }^{13}$ jumlah penduduk miskin di wilayah ini berada di urutan ke lima di Propinsi Lampung pada tahun 2010, yaitu sebesar 128.600 jiwa atau 14,58 persen dari total populasi.

Upaya untuk mengatasi persoalan kemiskinan dan ketimpangan pendapatan di Bandar Lampung telah dilakukan oleh pemerintah kota dan masyarakat setempat. Diantara upaya yang dilakukan oleh masyarakat adalah pendayagunaan dana ZIS melalui Lembaga Amil Zakat. Di Bandar Lampung terdapat dua lembaga amil zakat yaitu Lembaga Amil Zakat Dompet Amal Insani (LAZDAI) dan Dompet Peduli Ummat Daarut Tauhid (DPU-DT). Pendayagunan ZIS oleh dua LAZ tersebut diduga memberikan dampak positif terhadap penurunan tingkat kemiskinan dan ketimpangan pendapatan.

Penelitian-penelitian tentang dampak empiris ZIS terhadap penurunan kemiskinan dan ketimpangan pendapatan perlu dilakukan. Hal ini untuk meyakinkan pengambil keputusan (pemerintah) tentang pentingnya ZIS dalam pengentasan kemiskinan dan ketimpangan pendapatan, sehingga mau mengintegrasikan ZIS ke dalam kebijakan pembangunan nasional. Atas dasar hal tersebut, maka penulis tertarik untuk melakukan penelitian tentang peran ZIS terhadap penurunan kemiskinan dan ketimpangan pendapatan, dengan mengambil studi kasus LAZDAI dan DPU-DT kota Bandar Lampung.

Berdasarkan latar belakang di atas, ada beberapa permasalahan yang akan dijawab dalam penelitian ini, yaitu:

1. Apakah dana ZIS yang telah didistribusikan LAZDAI \& DPU DT memiliki dampak positif terhadap penurunan tingkat kemiskinan keluarga mustahik, yang meliputi insiden kemiskinan, kedalaman kemiskinan dan keparahan kemiskinan?

2. Berapa lama waktu yang diperlukan LAZDAI dan DPU DT untuk mengentaskan kemiskinan rumah tangga mustahik?

${ }^{11}$ IZDR 2011, Kajian Empiris Zakat Dalam pengentasan Kemiskinan, Ciputat: IMZ 2011, hal. 4.

${ }^{12}$ BPS, Berita Resmi Statistik, No. 6/01/th. XV, 2 Januari 2012, hal.8.

${ }^{13}$ BPS, Data dan Informasi Kemiskinan Kabupaten/Kota 2010, hal. 11 (Soft Copy) 

adalah:

Berdasarkan perumusan masalah di atas, maka tujuan dari penelitian ini

1. Menganalisa dampak distribusi ZIS oleh LAZDAI dan DPU DT terhadap tingkat kemiskinan keluarga mustahik, yang meliputi insiden kemiskinan, kedalaman kemiskinan dan keparahan kemiskinan.

2. Menganalisa lama waktu yang dibutuhkan oleh LAZDAI dan DPU DT untuk mengentaskan kemiskinan rumah tangga mustahik.

Sejumlah penelitian empirik tentang dampak pendayagunaan zakat terhadap pengurangan kemiskinan dan kesenjangan pendapatan telah dilakukan. Beik $(2010)^{14}$ telah melakukan penelitian mengenai peran zakat dalam pengentasan kemiskinan dan kesenjangan pendapatan dengan mengambil studi kasus pada program pendistribusian zakat di Badan Amil Zakat Nasional (BAZNAS), BAZIS DKI Jakarta dan Dompet Dhuafa Republika. Pada penelitian ini, untuk mengukur dampak zakat terhadap beban kemiskinan digunakan lima indeks kemiskinan, yaitu Headcount Ratio Index (H) untuk mengetahui jumlah kemiskinan, Poverty Gap Ratio (P1) dan Income Gap Ratio (1) untuk mengukur tingkat kedalaman kemiskinan, serta Sen Index of Poverty (P2), dan FGT Index (P3) untuk mengukur tingkat keparahan kemiskinan. Sedangkan untuk mengukur dampak zakat terhadap kesenjangan pendapatan digunakan rasio Gini dan kurva Lorenz. Penelitian ini dilakukan terhadap 1.195 rumah tangga mustahik yang berada di DKI Jakarta. Hasil penelitian menunjukkan bahwa setelah adanya distribusi zakat, indeks-indeks kemiskinan dan rasio Gini mengalami penurunan. Hal ini membuktikan bahwa meski dana zakat masih kecil, namun memiliki dampak nyata terhadap upaya pengentasan kemiskinan dan kesenjangan pendapatan.

Tiara Tsani(2010) ${ }^{15}$ juga telah melakukan penelitian tentang dampak distribusi zakat terhadap tingkat kemiskinan dan kesenjangan pendapatan, dengan mengambil studi kasus pendayagunaan zakat oleh BAZDA Lampung Selatan. Tiara menggunakan sejumlah alat analisis yang sama dengan alat analisis yang digunakan dalam penelitian Beik (2010) di atas. Penelitian ini mengambil sampel sebanyak 120 responden, yang terdiri dari 80 mustahik dan 40 muzakki. Hasil penelitian ini secara umum menunjukkan bahwa setelah distribusi zakat, semua indeks kemiskinan dan rasio Gini mengalami penurunan. Hal ini berarti

${ }^{14}$ Beik, Irfan Syauqi, Peran Zakat Mengentaskan Kemiskinan dan Kesenjangan, dalam Iqthishodia, Jurnal Ekonomi Islam Republika, Republika, 29 juli 2010, hal.8.

${ }^{15}$ Tiara Tsani, dalam skripsinya : Analisis Dampak Distribusi Zakat Terhadap Tingkat Kemiskinan dan Kesenjangan Pendapatan (Studi Kasus Pendayagunaan Zakat Oleh BAZDA Lampung Selatan), Bogor: Fakultas Ekonomi dan Manajemen IPB 2010. 
distribusi zakat oleh BAZDA Lampung Selatan memberikan dampak positif terhadap penurunan tingkat kemiskinan dan kesenjangan pendapatan.

Tim IMZ (2011) ${ }^{16}$ telah melakukan riset tentang kinerja zakat dalam pengentasan kemiskinan. Dalam penelitian ini, ada 8 lembaga zakat yang turut berpartisipasi untuk diteliti, yaitu BAZIS DKI, Dompet Dhuafa, DPU-DT, BMM, YBM BRI, BAMUIS BNI, BAZMA Pertamina, dan PKPU. Sampel yang diambil sebanyak 821 rumah tangga mustahik atau sekitar 17,67 persen dari total populasi yang tinggal di wilayah Jakarta, Bogor, Depok, Tangerang dan Bekasi. Alat analisa yang digunakan pada penelitian ini adalah Headcount ratio, Poverty gap ratio (P1), Income gap ratio (1), Sen index poverty (P2), dan FGT Index (P3). Hasil penelitian menunjukkan bahwa setelah adanya distribusi zakat, indeksindeks kemiskinan mustahik mengalami penurunan. Hal ini berarti bahwa distribusi zakat secara umum terbukti mampu mengurangi jumlah kemiskinan mustahik, tingkat kedalaman kemiskinan dan tingkat keparahan kemis kinan.

Penelitian ini dilakukan pada bulan November hingga Desember 2012. Lokasi yang dijadikan sebagai tempat penelitian adalah sepuluh dari tiga belas kecamatan yang ada di Bandar Lampung yang menjadi tempat pelaksanaan program pendayagunaan ZIS oleh LAZDAI dan DPU DT Bandar Lampung. Tiga belas kecamatan tersebut adalah Teluk Betung Barat (TBB), Teluk Betung Selatan (TBS), Panjang, Tanjung Karang Timur,Teluk Betung Utara (TBU), Tanjung Karang Pusat (TKP), Tanjung Karang Barat (TKB), Kemiling, Kedaton, Raja Basa, Tanjung Seneng, Suka Rame dan Suka Bumi.

Pemilihan lokasi ini dikarenakan oleh beberapa alasan pokok, yaitu :

1. LAZDAI dan DPU DT merupakan dua diantara beberapa OPZ di Provinsi Lampung yang telah cukup lama beroperasi, dengan penerima manfaat yang cukup banyak. Namun demikian, sampai dengan penelitian ini dilakukan, belum ada satupun yang meneliti tentang kinerja pendayagunaan ZIS oleh dua OPZ ini terhadap pengentasan kemiskinan. Hasil dari penelitian ini diharapkan bisa menjadi bahan evaluasi bagi dua OPZ terkait untuk meningkatkan kualitas pengelolaan zakat secara terus menerus (continous improvement).

2. Sebagai ibu kota provinsi, Bandar Lampung merupakan wilayah yang kondisi infrastruktur dan transportasinya relatif baik, sehingga memudahkan proses survey dan wawancara lapangan.

3. Karena keterbatasan sumber dana.

\section{HASIL DAN DISKUSI}

${ }^{16}$ IZDR 2011, Kajian Empiris Zakat Dalam pengentasan Kemiskinan, Ciputat: IMZ 2011, hal. 15-51. 
Berdasarkan hasil perhitungan uji $\mathrm{t}$-statistik diperoleh nilai $\mathrm{t}_{\text {bit }}(19,7103)$ lebihbesardari $\mathrm{t}_{\text {tabe }}(1,6531)$ sehingga tolak $\mathrm{H}_{0}$. Artinya, pendapatan setelah ZIS berbeda nyata pada taraf $\alpha=5 \%$ terhadap pendapatan tanpa ZIS (Lampiran 2). Sehingga bisa disimpulkan bahwa pemberian ZIS kepada mustabik memberikan pengaruh nyata pada tingkat pendapatannya.

Untuk mengetahui dampak distribusi ZIS terhadap tingkat kemiskinan dilakukan pembandingan indikator-indikator sebelum dan sesudah distribusi ZIS. Apabila terdapat perbedaan pada setiap indikator setelah distribusi ZIS maka pendistribusian ZIS tersebut diindikasikan berdampak bagi kesejahteraan masyarakat yang bernilai positif maupun negatif. Sebaliknya, apabila pada setiap indikator tidak menunjukan perbedaan atau sama dengan sebelum distribusi ZIS, hal ini mengindikasikan bahwa pendistribusian ZIS belum memberikan dampak bagi kesejahteraan masyarakat. Kesejahteraan masyarakat membaik atau menurun akan dilihat dari sisi perubahan beban kemiskinan.

\subsection{Analisa Kemiskinan Secara Umum}

Suatu program penanggulangan kemiskinan dapat dikatakan berperan positif apabila mampu mengurangi beban kemiskinan.Program tersebut tidak dapat diketahui pengaruhnya terhadap beban kemiskinan apabila tidak dilakukan kajian dan evaluasi. Pendistribusian zakat yang dilakukan oleh OPZ bertujuan mengurangi beban kemiskinan di masyarakat baik melalui bantuan karitatif atau bantuan produktif. Namun, apakah tujuan tersebut telah tercapai atau gagal serta bila tercapai seberapa besar ZIS dapat mengurangi beban kemiskinan. ${ }^{17}$ Adapun hasil penelitian kinerja ZIS dalam mengurangi beban kemiskinan mustahik secara umum terangkum dalam tabel 5.2 berikut ini.

Tabel 5.2. Analisa Kemiskinan Secara Umum

\begin{tabular}{|l|c|c|c|}
\hline \multicolumn{1}{|c|}{$\begin{array}{c}\text { Indeks } \\
\text { Kemiskinan }\end{array}$} & Tanpa Zakat & Dengan Zakat & $\begin{array}{c}\text { Prosentase } \\
\text { Perubahan }\end{array}$ \\
\hline H & 0,785 & 0,774 & 1,37 \\
\hline P1 $(\mathrm{Rp})$ & 995948,973 & 914543,403 & 8,17 \\
\hline I & 0,395 & 0,363 & 8,17 \\
\hline P2 & 0,405 & 0,374 & 7,76 \\
\hline P3 & 0,158 & 0,136 & 13,82 \\
\hline
\end{tabular}

\footnotetext{
${ }^{17}$ IZDR 2012, Membangun Peradaban Zakat Indonesia: Soal Kebijakan dan Hal Lain yang Belum

Paripurna, Ciputat; IMZ 2012, hlm.49
}

77 | Jurnal Bina Ummat | Vol.2 | No.1| 2019 


\begin{tabular}{|l|l|l|l|}
\hline $\begin{array}{l}\text { Time Taken to } \\
\text { Exit }\end{array}$ & 14,2 & 13,1 & - \\
\hline
\end{tabular}

\subsubsection{Insiden Kemiskinan}

Insiden kemiskinan atau banyaknya jumlah orang miskin diukur dengan menggunakan Headcount Ratio Index $(\mathrm{H})$. Pada penelitian ini, indeks Headcount digunakan untuk melihat berapa jumlah rumah tangga miskin yang mampu direduksi melalui pendayagunaan ZIS. Pada tabel 5.2 di atas, terlihat nilai beadcount sebelum ZIS adalah 0,785. Ini menunjukkan bahwa dari seluruh rumah tangga penerima ZIS(mustabik) yang diamati, 78,5 persennya dikategorikan miskin berdasarkan garis kemiskinan keluarga.

Besarnya presentase rumah tangga miskin tersebut karena garis kemiskinan yang digunakan dalam penelitian ini bukan garis kemiskinan menurut standar BPS, melainkan garis kemiskinan yang didasarkan pada nishab (emas).Karena nilai indeks headcount sangat bergantung pada garis kemiskinan maka penggunaan garis kemiskinan yang berbeda dapat menghasilkan presentase RTM yang berbeda pula.Penggunaan garis kemiskinan berdasarkan standar nishab dalam penelitian ini karena lebih rasional dalam konteks perekonomian nasional sekarang.

Setelah pendistribusian ZIS, nilai indeks beadcount turun dari 0,785 menjadi 0,774 . Dengan kata lain, presentase rumah tangga miskin berkurang sebesar 1,1 poin atau presentase perubahannya 1,37 persen. Jika dianalisa lebih dalam, kecilnya perubahan nilai beadcount index pasca ZIS diduga disebabkan oleh (setidaknya) dua hal. Pertama, adanya prioritas penyaluran dengan angka yang lebih besar kepada mustabik tertentu yang telah ditentukan. Kedua, jumlah mustahik penerima dana ZIS relatif banyak, sehingga dana ZIS yang didistribusikan secara umum relatif kecil.

Meskipun perubahan persentase insiden kemiskinan sangat sedikit sekali, tetapi ini mengindikasikan bahwa program ZIS yang telah dilakukan terbukti secara empiris mampu mengurangi jumlah kemiskinan mustabik. Ini juga membuktikan implikasi positif dalam pengentasan kemiskinan apabila dikelola oleh lembaga zakat yang amanah dan profesional.

\subsubsection{Kedalaman Kemiskinan}

Jurang (kedalaman) kemiskinan dan kisaran biaya yang diperlukan untuk menutupinya ditunjukkan oleh indeks poverty gap $\left(\mathrm{P}_{1}\right)$ dan income gap (I). Pada tabel 5.2 terlihat bahwa tanpa ZIS, nilai poverty gap $\left(\mathrm{P}_{1}\right)$ Rp 995.948,97 dan setelah distribusi ZIS nilainya turun menjadi Rp. 914.543,40. Artinya, pada awalnya defisit rata-rata pendapatan rumah tangga miskin dengan garis kemiskinan adalah 
Rp 995.948,97 dan setelah distribusi ZIS, defisit pendapatan berkurang menjadi Rp 914.543,40. Penurunan nilai indeks tersebut mengindikasikan bahwa rata-rata pendapatan (atau pengeluaran) rumah tangga miskin cenderung makin mendekati garis kemiskinan. Dengan kata lain, biaya yang dibutuhkan untuk mengentaskan kemiskinan rata-rata berkurang Rp 995.948,97 / rumah tangga /bulan menjadi Rp. 914.543,40 / rumah tangga / bulan dengan catatan tanpa biaya transaksi dan faktor penghambat (transfer sempurna).

Hal yang sama terjadi pada indeks income gap yang berkurang dari 0,395 menjadi 0,363 setelah distribusi ZIS. Interpretasi indeks income gap ini sama dengan poverty gap. Hanya indeks income gap dalam bentuk persentase dari garis kemiskinan. Maka, nilai income gap tersebut di atas berarti bahwa rata-rata defisit pendapatan rumah tangga miskin turun dari 39,5 persen menjadi 36,3 persen dari garis kemiskinan. Atau dengan kata lain, biaya pengentasan kemiskinan berkurang dari 39,5 persen menjadi 36,3 persen dari garis kemiskinan (per rumah tangga per bulan) dengan catatan tanpa biaya transaksi dan faktor penghambat (transfer sempurna).

\subsubsection{Keparahan Kemiskinan}

Penurunan indeks kedalaman kemiskinan diikuti dengan penurunan indeks keparahan kemiskinan. Indeks sen mengalami penurunan sebesar 7,76 persen dari 0,405 menjadi 0,374. Begitu pula dengan indeks FGT yang turun sebesar 13,82 persen dari 0,158 menjadi 0,136. Dengan demikian, setelah pendistribusian ZIS ketimpangan pendapatan (atau pengeluaran) di antara rumah tangga miskin semakin rendah. Dengan kata lain, keberadaan ZIS menjadikan distribusi pendapatan antara keluarga miskin menjadi lebih merata dibandingkan sebelum ZIS didistribusikan kepada mereka.

Berdasarkan ketiga indeks kemiskinan tersebut, maka dapat disimpulkan bahwa secara umum instrumen ZIS memiliki implikasi positif dalam mengurangi beban kemiskinan seperti mengurangi jumlah rumah tangga miskin, tingkat kedalaman kemiskinan dan tingkat keparahan kemiskinan.

\subsubsection{Analisa Time Taken to Exit}

Distribusi ZIS selain memiliki implikasi positif dalam mengurangi beban kemiskinan, juga memiliki implikasi positif dalam mengurangi kisaran waktu yang dibutuhkan untuk mengentaskan kemiskinan. Kolom time taken to exit pada tabel 5.2 di atas menunjukkan peran ZIS sebagai program penanggulangan kemiskinan oleh OPZ dapat mempercepat proses pengentasan kemiskinan. Dengan asumsi tingkat pertumbuhan ekonomi berkelanjutan dan terdistribusi normal pada seluruh masayarakat miskin, diperlukan waktu selama 14,2 tahun dengan tingkat pertumbuhan ekonomi yang dinikmati keluarga miskin 1 persen tiap tahunnya. 
Akan tetapi, setelah pendistribusian ZIS di Bandar Lampung, waktu pengentasan tersebut mampu dipersingkat 1,1 tahun dari 14,2 tahun menjadi 13,1 tahun.

\subsection{Analisa Berdasarkan Determinan Kemiskinan}

Profil kemiskinan ditujukan untuk mengkaji pola kemiskinan sehingga dapat memperlihatkan fakta-fakta kemiskinan (insiden dan kesenjangan) dan mengetahui variasi pola kemiskinan berdasarkan geografi/wilayah dan karakteristik rumah tangga/individu. Oleh karena itu, profil kemiskinan merupakan perbandingan kemiskinan yang komprehensif dengan menunjukkan bagaimana kemiskinan bervariasi di seluruh sub kelompok masyarakat seperti daerah tempat tinggal atau sektor pekerjaan. ${ }^{18}$

Pada bagian ini akan dipaparkan pola kemiskinan berdasarkan karakteristik rumah tangga/individu ${ }^{19}$ secara deskriptif dan penggunaan tabel guna mengetahui risiko miskin (risk of being poor) yang dilihat dari indeks kemiskinan sebelum presentase memperoleh ZIS dan presentase penurunan beban kemiskinan di tiap kelompok rumah tangga yang berbeda yang dilihat dari perubahan indiks kemiskinan setelah memperoleh zakat.

\subsubsection{Analisa Kemiskinan Berbasis Jenis Kelamin Kepala Rumah Tangga.}

Kepala keluarga adalah orang yang memiliki tanggung jawab yang tertinggi dalam mengelola rumah tangga, baik laki-laki maupun perempuan. ${ }^{20}$ Jenis kelamin kepala rumah tangga sangat mempengaruhi kinerja sebuah rumah tangga. ${ }^{21}$ Dalam kaitannya dengan aspek jenis kelamin, penelitian ini mencoba untuk menganalisa dampak program pendayagunaan ZIS terhadap rumah tangga yang dipimpin laki-laki maupun perempuan.

Grafik 5.1 Analisa Kemiskinan Berdasarkan Jenis Kelamin Kepala Rumah Tangga

\footnotetext{
${ }^{18}$ IZDR 2012, Membangun Peradaban Zakat Indonesia: Soal Kebijakan dan Hal Lain yang Belum

Paripurna, Ciputat; IMZ 2012, hlm.55

${ }^{19}$ Pola kemiskinan berdasarkan geografi/wilayah tidak dianalisa dalam penelitian ini.

${ }^{20}$ IZDR 2012, Membangun Peradaban Zakat Indonesia: Soal Kebijakan dan Hal Lain yang

Belum

Paripurna, Ciputat; IMZ 2012, hlm. 56

${ }^{21} \mathrm{Ibid}, \mathrm{h} / \mathrm{m} .29$
} 


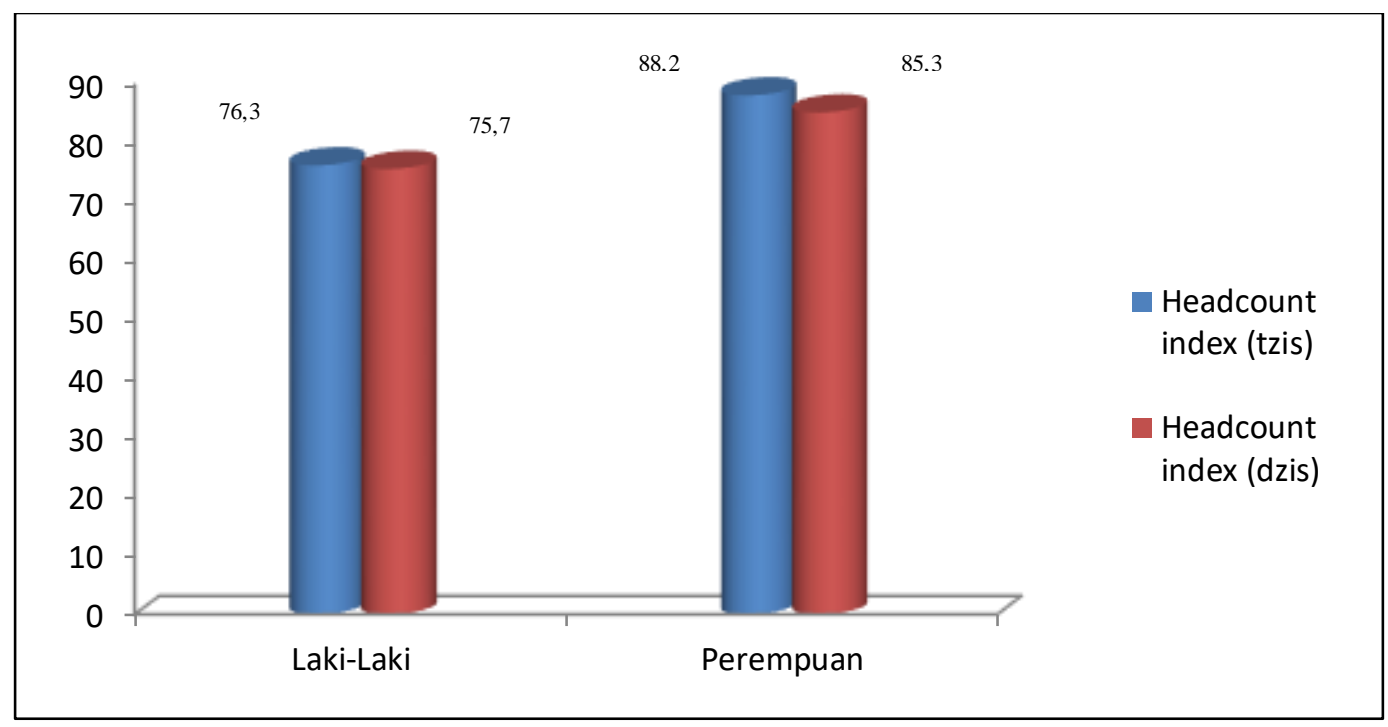

Pada Grafik 5.1 terlihat bahwa insiden kemiskinan pada kelompok rumah tangga dengan kepala keluarga perempuan lebih tinggi dibandingkan kepala keluarga laki-laki. Temuan ini mengindikasikan bahwa kepala keluarga perempuan lebih rentan terhadap kemiskinan sehingga keberadaannya perlu diperhatikan mengingat kepala keluarga perempuan pada umumnya harus menghidupi anggota keluarganya sendiri. Special treatment bagi kepala rumah tangga berjenis kelamin perempuan harus dilakukan seoptimal mungkin.

Dari grafik 5.1 dapat dianalisa bahwa sebelum menerima ZIS, tingkat kemiskinan pada rumah tangga dengan kepala keluarga perempuan sebesar 88,2 persen dari total populasi. Lebih tinggi 11,9 persen dari kepala keluarga laki-laki. Kemudian terjadi pengurangan insiden kemiskinan setelah distribusi ZIS dengan penurunan terbesar terjadi pada kepala keluarga perempuan. Penurunan nilai beadcount index sebesar 3,33 persen untuk kepala keluarga perempuan dan 0,86 persen untuk kepala keluarga laki-laki. Hal ini membuktikan bahwa instrumen ZIS memiliki implikasi positif dalam mereduksi tingkat kemiskinan rumah tangga di kedua kelompok tersebut meskipun nilainya masih sangat kecil.

Tabel 5.3 Analisa Kemiskinan Berbasis Jenis Kelamin Kepala Rumah Tangga

\begin{tabular}{|l|l|l|l|l|l|c|}
\hline \multirow{2}{*}{$\begin{array}{l}\text { Indikator } \\
\text { Kemiskinan }\end{array}$} & \multicolumn{2}{|l|}{ Laki-Laki } & \multicolumn{2}{l|}{ Perempuan } & \multicolumn{2}{l|}{ Perubahan (\%) } \\
\cline { 2 - 7 } & TZIS & DZIS & TZIS & DZIS & Lk & Pr \\
\hline P1(Rp) & $\begin{array}{l}952956,4 \\
7\end{array}$ & 873703,91 & $\begin{array}{l}1162186,6 \\
7\end{array}$ & $\begin{array}{l}1076493,1 \\
0\end{array}$ & 8,32 & 7,37 \\
\hline I & 0,378 & 0,347 & 0,461 & 0,427 & 8,32 & 7,37 \\
\hline P2 & 0,372 & 0,344 & 0,544 & 0,496 & 7,40 & 8,80 \\
\hline
\end{tabular}




\begin{tabular}{|l|l|l|l|l|l|l|}
\hline P3 & 0,136 & 0,117 & 0,253 & 0,218 & 13,80 & 13,86 \\
\hline $\begin{array}{l}\text { Time Taken } \\
\text { to Exit }\end{array}$ & 12,9 & 12,1 & 19,8 & 17,4 & - & - \\
\hline
\end{tabular}

Dari tabel 5.3 terlihat bahwa tingkat kedalaman kemiskinan dan keparahan kemiskinan pada kelompok keluarga dengan kepala keluarga perempuan lebih tinggi dibandingkan laki-laki. Fakta ini menunjukkan bahwa beban kemiskinan yang dialami kelompok keluarga dengan kepala keluarga perempuan lebih berat. Kondisi ini antara lain disebabkan para perempuan tersebut pada umumnya memiliki tingkat pendidikan yang rendah sehingga kesempatan untuk memperoleh pekerjaan yang layak di sektor formal sangat terbatas. Faktor lainnya, tidak banyak dari para perempuan yang memiliki kemampuan yang baik dalam berbisnis, berbeda dengan para laki.

Distribusi ZIS memiliki implikasi positif terhadap pengurangan tingkat kedalaman kemiskinan baik pada kelompok kepala keluarga laki-laki maupun kepala keluarga perempuan. Pada awalnya rata-rata defisit pendapatan rumah tangga dengan garis kemiskinan (P1) sebesar Rp. 952956,47/bulan untuk kepala keluarga laki-laki dan Rp 1162186,67/bulan untuk kepala keluarga perempuan. Setelah distribusi ZIS defisit anggaran tersebut dapat diperkecil menjadi Rp.873703,91 untuk kepala keluarga pria dan Rp.1076493,10 untuk kepala keluarga perempuan. Demikian pula dengan prosentase rata-rata kesenjangan pendapatan rumah tangga miskin (I) yang berkurang dari 0,372 menjadi 0,347 untuk kepala keluarga laki-laki dan dari 0,461 menjadi 0,427 untuk kepala keluarga perempuan. Prosentase penurunan kedua indeks di atas mencapai 8,32 persen untuk kepala keluarga pria dan 7,37 untuk kepala keluarga wanita.

Dari sisi keparahan kemiskinan, indeks Sen dan indeks FGT untuk kepala keluarga laki-laki dan kepala keluarga perempuan sama-sama mengalami penurunan. Penurunan pada kelompok kepala keluarga perempuan sedikit lebih tinggi dari kelompok kepala keluarga laki-laki. Prosentase penurunan indeks Sen dan indeks FGT untuk kepala keluarga perempuan masing-masing adalah 8,80 persen dan 13,86 persen. Sedangkan untuk kepala keluarga laki-laki adalah 7,40 persen dan 13,80 persen. Penurunan pada kedua indeks ini mengindikasikan bahwa program ZIS dapat memperbaiki kondisi kehidupan rumah tangga miskin. Dengan keberadaan ZIS, distribusi pendapatan antara keluarga miskin menjadi lebih merata dibandingkan sebelum ZIS diditribusikan kepada mereka.

Dari hasil temuan fakta di atas dapat disimpulkan bahwa program ZIS belum memberikan dampak signifikan tehadap pengurangan insiden kemiskinan baik pada kelompok rumah tangga yang dipimpin kepala keluarga laki-laki maupun perempuan. Kinerja rumah tangga yang dipimpin kepala keluarga perempuan lebih baik dalam hal penurunan insiden kemiskinan. Distribusi ZIS 
menunjukkan kinerja yang lebih baik dalam mereduksi tingkat kedalaman kemiskinan dan keparahan kemiskinan. Presentase pengurangan tingkat kedalaman kemiskinan dan keparahan pada kelompok wanita hampir sama dengan kelompok pria. Hal ini mengindikasikan bahwa kinerja kedua kelompok tersebut relatif sama.

Tabel 5.4 Time Taken to Exit Berdasarkan Jenis Kelamin Kepala Rumah Tangga

\begin{tabular}{|l|c|c|}
\hline \multicolumn{1}{|c|}{$\begin{array}{c}\text { Jenis Kelamin Kepala } \\
\text { Keluarga }\end{array}$} & Pra ZIS & Pasca ZIS \\
\hline Pria & 12,9 tahun & 12,1 tahun \\
\hline Wanita & 19,8 tahun & 17,4 tahun \\
\hline
\end{tabular}

Hal lain yang patut diperhatikan adalah kisaran waktu yang dibutuhkan untuk mengentaskan kemiskinan. Kolom Time Taken to Exit pada tabel 5.4 di atas menginformasikan bahwa untuk mengentaskan kemiskinan seluruh kelompok kepala keluarga wanita membutuhkan waktu yang lebih panjang dibandingkan dengan kelompok keluarga pria. Perlu waktu 19,8 tahun untuk mengeluarkan kepala keluarga wanita dari kemiskinan. Sedangkan kepala keluarga pria membutuhkan waktu 12,9 tahun. Distribusi ZIS dapat mempersingkat waktu pengentasan kemiskinan sebesar 2,4 tahun untuk kepala keluarga wanita dan 10 bulan untuk kepala keluarga pria. Temuan ini menunjukkan peran positif instrument ZIS dalam mempercepat waktu pengentasan kemiskinan.

\subsubsection{Analisa Kemiskinan Berbasis Status Pernikahan}

Status pernikahan kepala rumah tangga adalah menjadi salah satu faktor yang mempengaruhi kemiskinan. Dalam penelitian ini status pernikahan ini dibagi kepada dua kelompok besar yaitu menikah (orang tua lengkap) dan tidak menikah (orang tua tunggal/single). Status tidak menikah ini bisa jadi dalam kondisi belum menikah, janda/duda akibat cerai, atau janda/duda akibat ditinggal wafat. Kepala keluarga dengan status menikah sebanyak 79,57 persen, dan status tunggal sebanyak 20,43 persen.

Grafik 5.2 Analisa Kemiskinan Berdasarkan Jenis status pernikahan Kepala Rumah Tangga 


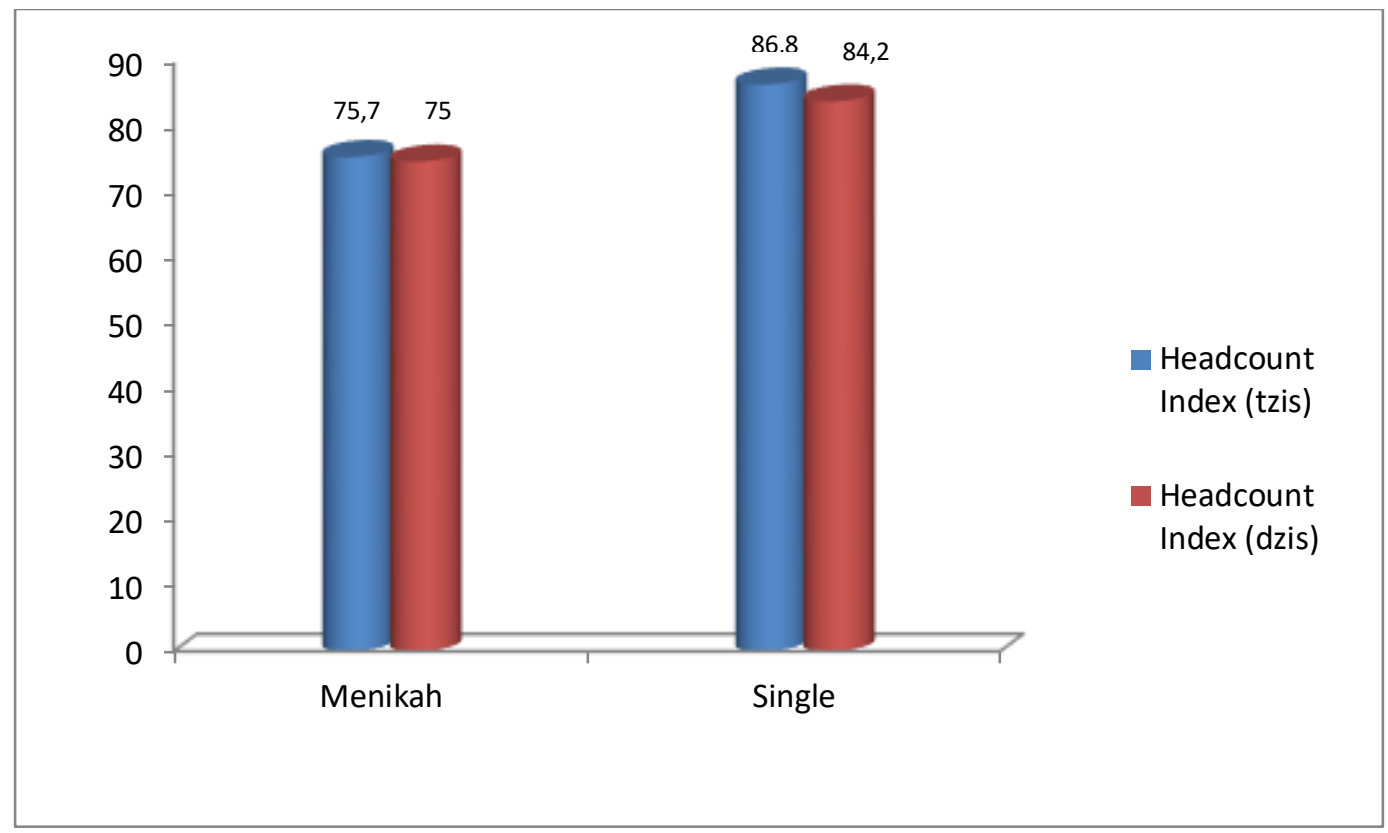

Dari grafik 5.2 terlihat bahwa sebelum distribusi ZIS, jumlah rumah tangga miskin dengan orang tua tunggal adalah 86,8 persen. Lebih tinggi 11,1 persen dari rumah tangga berstatus menikah (orang tua lengkap) yang tingkat kemiskinannya mencapai 75,7 persen. Temuan ini mengindikasikan bahwa rumah tangga dengan orang tua tunggal lebih rentan terhadap kemiskinan. Menurut Kimmel (1980) ${ }^{22}$ orang tua tunggal menghadapi kesulitan dalam memperoleh pekerjaan yang layak,pendapatan yang cukup untuk biaya sekolah dan kebutuhan hidup lainnya. Apalagi mereka harus membagi waktu antara bekerja, mengurus rumah, dan anak-anak. Belum lagi tekanan yang harus dihadapi dalam mengurus dan membesarkan anak sendirian, kurangnya dukungan sosial dalam menjalankan perannya sebagai orang tua, dan fisiknya yang rentan terhadap penyakit. Keadaan inilah yang menyebabkan keluarga dengan orang tua tunggal lebih rentan terhadap kemiskinan dan sulitnya keluar dari kemiskinan yang membelenggunya.

Pasca distribusi ZIS, insiden kemiskinan pada rumah tangga dengan orang tua tunggal berkurang sebesar 2,6 poin atau prosentase perubahannya mencapai 3,03 persen. Sedangkan rumah tangga berstatus menikah hanya turun sebesar 0,7 poin atau prosentase perubahannya mencapai 0,89 persen. Ini mengindikasikan bahwa program pendayagunaan ZIS yang telah dilakukan, terbukti mampu menurunkan incidence kemiskinan meskipun prosentase penurunannya masih sangat kecil.

\footnotetext{
${ }^{22}$ Dalam IZDR 2012, Membangun Peradaban Zakat Indonesia: Soal Kebijakan dan Hal Lain yang BelumParipurna, Ciputat; IMZ 2012, hlml.58-59.
} 
Tabel 5.5 Analisa Kemiskinan Berdasarkan Status Pernikahan Kepala Rumah Tangga

\begin{tabular}{|l|c|c|c|c|c|c|}
\hline \multirow{2}{*}{$\begin{array}{c}\text { Indikator } \\
\text { Kemiskinan }\end{array}$} & \multicolumn{2}{|c|}{$\begin{array}{c}\text { Menikah/Orang Tua } \\
\text { Lengkap }\end{array}$} & \multicolumn{2}{|c|}{ Orang Tua Tunggal } & \multicolumn{2}{|c|}{ Perubahan (\%) } \\
\cline { 2 - 7 } & TZ & DZ & TZ & DZ & $\begin{array}{c}\text { Orang } \\
\text { Tua } \\
\text { Lengka } \\
\mathrm{p}\end{array}$ & $\begin{array}{c}\text { Orang } \\
\text { Tua } \\
\text { Tunggal }\end{array}$ \\
\hline P1(Rp) & $\begin{array}{c}937365,6 \\
2\end{array}$ & $\begin{array}{c}858688,7 \\
4\end{array}$ & $\begin{array}{c}1181927, \\
27\end{array}$ & $\begin{array}{c}1137024, \\
24\end{array}$ & 8,39 & 3,80 \\
\hline I & 0,372 & 0,341 & 0,469 & 0,434 & 8,39 & 7,46 \\
\hline P2 & 0,364 & 0,337 & 0,538 & 0,481 & 7,49 & 10,65 \\
\hline P3 & 0,131 & 0,113 & 0,252 & 0,217 & 14,00 & 13,71 \\
\hline
\end{tabular}

Dari tabel 5.5 terlihat bahwa tingkat kedalaman kemiskinan dan keparahan kemiskinan pada kelompok keluarga yang dipimpin orang tua tunggal lebih tinggi dibanding kelompok keluarga dengan orang tua lengkap. Hal ini menunjukkan bahwa beban kemiskinan yang dialami keluarga dengan orang tua tunggal relatif lebih berat.

Program pendayagunaan ZIS oleh OPZ dalam penelitian ini memiliki andil dalam memperkecil jurang (kedalaman) kemiskinan dan menurunkan tingkat keparahan kemiskinan di kedua kelompok tersebut. Dari sisi kedalaman kemiskinan, hasil poverty gap dan income gap untuk kelompok rumah tangga dengan orang tua lengkap menunjukkan penurunan masing-masing sebesar 8,39 persen dari posisi angka sebelum terjadinya distribusi ZIS. Sedangkan untuk kelompok rumah tangga dengan orang tua tunggal, nilai poverty gap dan income gap mengalami reduksi masing-masing sebesar 3,80 persen dan 7,46 persen.

Sedangkan tingkat keparahan kemiskinan, pasca distribusi ZIS, indeks sen dan indeks FGT mengalami penurunan masing-masing sebesar 7,49 persen dan 14,00 persen untuk kelompok rumah tangga dengan orang tua lengkap. Sedangkan untuk kelompok rumah tangga dengan orang tua tunggal, nilai indeks sen dan indeks FGT mengalami penurunan masing-masing sebesar 10,65 persen dan 13,71 persen.

Dari fakta-fakta di atas dapat disimpulkan bahwa untuk insiden kemiskinan dan tingkat keparahan kemiskinan, penurunan tercepat terjadi pada rumah tangga dengan orang tua tunggal. Sedangkan untuk tingkat kedalaman kemiskinan, penurunan tercepat terjadi pada rumah tangga dengan orang tua lengkap. 
Tabel 5.6. Time Taken to Exit Berdasarkan Status Pernikahan Kepala Keluarga

\begin{tabular}{|l|c|c|}
\hline \multicolumn{1}{|c|}{ Status Pernikahan } & Pra ZIS & Pasca ZIS \\
\hline $\begin{array}{l}\text { Menikah / Orang Tua } \\
\text { Lengkap }\end{array}$ & 12,7 tahun & 12 tahun \\
\hline Orang Tua Tunggal & 19,5 tahun & 12 tahun \\
\hline
\end{tabular}

Tabel di atas menunjukkan peran ZIS sebagai program penanggulangan kemiskinan oleh OPZ dapat mempercepat proses pengentasan kemiskinan. Awalnya pengentasan kemiskinan di kelompok rumah tangga dengan orang tua lengkap memakan waktu 12,7 tahun, namun dengan adanya program ZIS waktu pengentasan kemiskinan dapat dipersingkat menjadi 12 tahun. Kinerja ZIS yang lebih baik terjadi pada kelompok rumah tangga orang tua tunggal dengan mempersingkat waktu pengentasan kemiskinan hingga 2,3 tahun dari 19,5 tahun menjadi 17,2 tahun.

\subsubsection{Analisa Kemiskinan Berdasarkan Usia Kepala Keluarga}

Usia kepala keluarga sangat menentukan kemampuan sebuah rumah tangga dalam membebaskan diri mereka dari kemiskinan. ${ }^{23}$ Umumnya usia yang tergolong tidak produktif akan memiliki risiko miskin lebih besar dibandingkan usia produktif. ${ }^{24}$ Pada penelitian ini, usia kepala rumah tangga dibagi kedalam tiga kelompok, yaitu usia 15-45 tahun, 46-64 tahun, dan di atas 64 tahun.

Grafik 5.3. Analisa Kemiskinan Berdasarkan Usia Kepala Keluarga

${ }^{23}$ IZDR 2011, Kajian Empiris Zakat Dalam pengentasan Kemiskinan, Ciputat: IMZ 2011, hlm.34

${ }^{24}$ IZDR 2012, Membangun Peradaban Zakat Indonesia: Soal Kebijakan dan Hal Lain yang

Belum

Paripurna, Ciputat; IMZ 2012, hal.61 


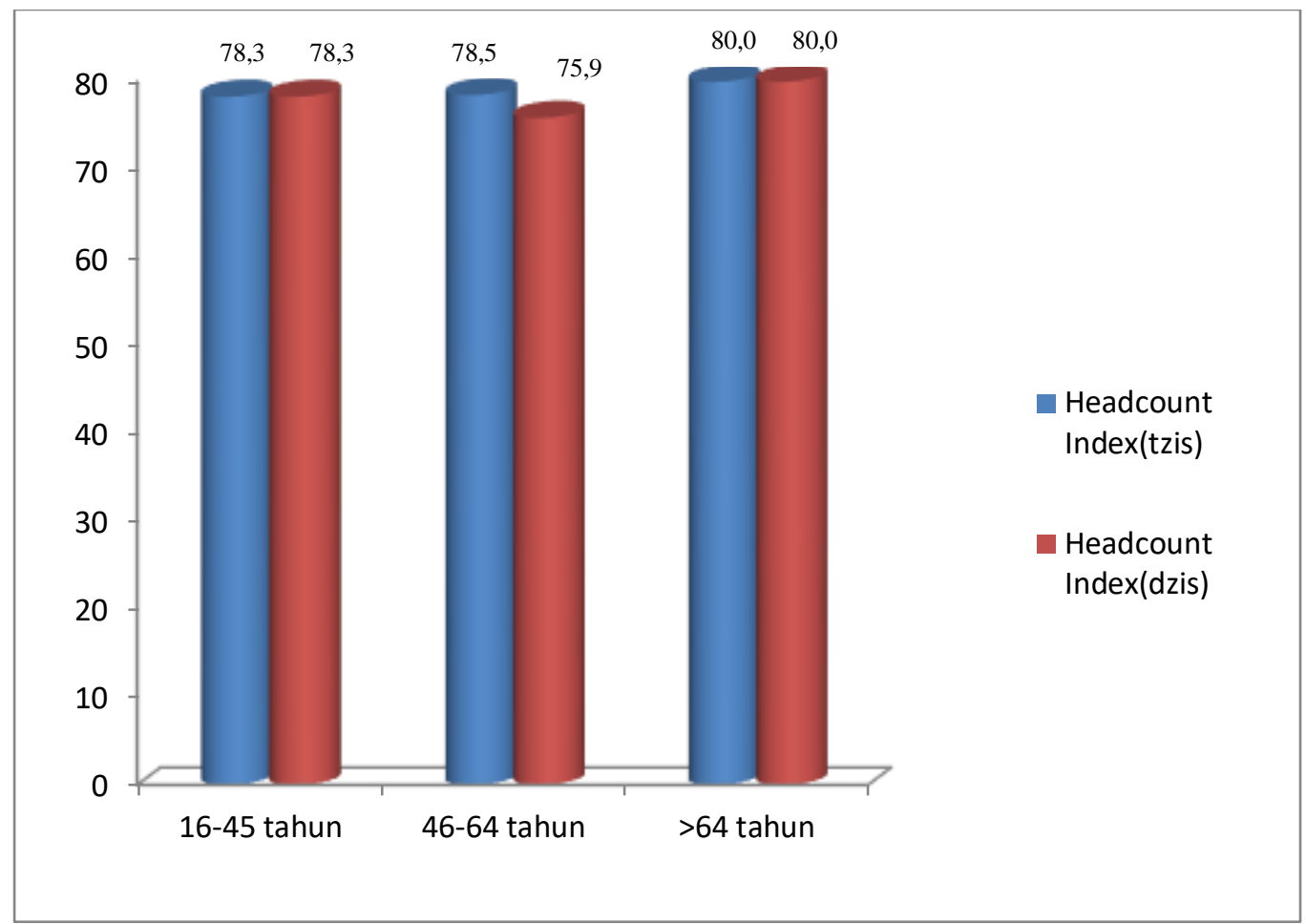

Grafik 5.3 di atas memperlihatkan kondisi insiden kemiskinan sebelum dan setelah ZIS didistribusikan kepada kelima kelompok tersebut. Pada grafik 5.3 terlihat bahwa angka kemiskinan pada semua kelompok usia hampir sama. Kelompok usia lebih dari 64 tahun (usia tidak produktif) memiliki angka kemiskinan sedikit lebih tinggi dibandingkan dua kelompok usia lainnya yaitu sebesar 80 persen. Sedangkan dua kelompok lainnya angka kemiskinannya adalah 78,5 persen untuk usia 46-64 tahun dan 78,3 persen untuk usia 16-45 tahun. Meskipun keadaan ini tidak biasa, namun temuan ini menunjukkan bahwa kelompok usia produktif memiliki kerentanan yang sama dengan kelompok usia tidak produktif.

Setelah distribusi ZIS, angka kemiskinan pada kelompok usia tidak produktif tidak ada perubahan atau sama dengan kondisi sebelum distribusi ZIS. Hal yang sama terjadi pada kelompok usia 16-45 tahun. Kinerja positif ZIS hanya terjadi pada kelompok usia 46-64 tahun, yang mana angka kemiskinannya turun 2,6 poin atau prosentase perubahannya sebesar 3,23 persen. Fakta ini menegaskan bahwa efektifitas program ZIS yang ada lebih besar pada kelompok usia 46-65 tahun.

Tabel 5.7 Analisa Kemiskinan Berbasis Usia Kepala Keluarga

\begin{tabular}{|l|c|c|c|c|c|c|}
\hline \multirow{2}{*}{$\begin{array}{l}\text { Indeks } \\
\text { Kemiskinan }\end{array}$} & \multicolumn{2}{|c|}{$15-45$} & \multicolumn{2}{|c|}{$46-64$} & \multicolumn{2}{|c|}{$>64$} \\
\cline { 2 - 6 } & TZ & DZ & TZ & DZ & TZ & DZ \\
\hline
\end{tabular}




\begin{tabular}{|c|c|c|c|c|c|c|}
\hline P1 (Rp) & $\begin{array}{c}103841 \\
1,81\end{array}$ & $\begin{array}{c}962979 \\
86\end{array}$ & $\begin{array}{c}915090,3 \\
2\end{array}$ & $\begin{array}{c}829901,6 \\
7\end{array}$ & $\begin{array}{c}1158941 \\
67\end{array}$ & 913236,36 \\
\hline $\begin{array}{l}\text { Perubahan } \\
(\%)\end{array}$ & \multicolumn{2}{|c|}{7,26} & \multicolumn{2}{|c|}{9,31} & \multicolumn{2}{|c|}{21,20} \\
\hline I & 0,412 & 0,382 & 0,363 & 0,329 & 0,460 & 0,416 \\
\hline $\begin{array}{l}\text { Perubahan } \\
(\%)\end{array}$ & \multicolumn{2}{|c|}{7,26} & \multicolumn{2}{|c|}{9,31} & \multicolumn{2}{|c|}{9,65} \\
\hline P2 & 0,416 & 0,395 & 0,379 & 0,338 & 0,478 & 0,475 \\
\hline $\begin{array}{l}\text { Perubahan } \\
(\%)\end{array}$ & \multicolumn{2}{|c|}{5,11} & \multicolumn{2}{|c|}{11,03} & \multicolumn{2}{|c|}{0,66} \\
\hline P3 & 0,164 & 0,147 & 0,138 & 0,113 & 0,216 & 0,184 \\
\hline $\begin{array}{l}\text { Perubahan } \\
(\%)\end{array}$ & \multicolumn{2}{|c|}{10,47} & \multicolumn{2}{|c|}{18,20} & \multicolumn{2}{|c|}{14,71} \\
\hline
\end{tabular}

Meskipun distribusi ZIS belum mampu mengurangi insiden kemiskinan dengan pengecualian pada kelompok usia 46-64 tahun, namun distribusi ZIS menunjukkan kinerja positif dalam memperkecil tingkat kedalaman kemiskinan dan tingkat keparahan kemiskinan pada semua kelompok usia. Tabel 5.7 di atas memperlihatkan implikasi positif ZIS terhadap penurunan tingkat kedalaman kemiskinan dan tingkat keparahan kemiskinan pada kelima kelompok usia tersebut.

Dari sisi tingkat kedalaman kemiskinan, penurunan terbesar terjadi pada kelompok usia lebih dari 64 tahun (tidak produktif) dengan prosentase perubahan sebesar 21,20 persen untuk nilai poverty index dan 9,65 persen untuk nilai income gap index. Sedangkan untuk kelompok usia 46-64 tahun, prosentase perubahan poverty index dan income gap index masing-masing adalah 9,31 persen. Yang terakhir, kelompok usia 16-45 tahun, prosentase perubahan kedua rasio tersebut masing-masing adalah 7,26 persen. Adanya penurunan pada poverty index dan income gap index seperti tersebut di atas menunjukkan bahwa distribusi ZIS mampu memperkecil defisit rata-rata pendapatan rumah tangga miskin dengan garis kemiskinan.

Dari sisi keparahan kemiskinan, penurunan tercepat terjadi pada kelompok usia 46-64 tahun. Untuk kelompok ini, nilai indeks Sen turun 11,03 persen dan indeks FGT turun 18,20 persen. Untuk kelompok usia 15-45 tahun, indeks Sen maupun indeks FGT menunjukkan penurunan masing-masing sebesar 5,108 persen dan 10,473 persen. Sedangkan kelompok usia tidak produktif, indeks Sen turun 0,66 persen dan indeks FGT turun 14,71 persen. Menurunnya index Sen dan index FGT ini mengindikasikan bahwa ketimpangan 
pendapatan/pengeluaran di antara rumah tangga miskin semakin rendah pasca distribusi ZIS. Dengan kata lain, keberadaan ZIS memiliki andil dalam memperbaiki tingkat distribusi pendapatan di antara rumah tangga miskin. Sehingga kehidupan mereka menjadi lebih baik.

Dari fakta-fakta di atas dapat disimpulkan bahwa distribusi ZIS memiliki implikasi positif terhadap pengurangan tingkat kedalaman kemiskinan dan tingkat keparahan kemiskinan rumah tangga. Untuk kedalaman kemiskinan, presentase pengurangan terbesar terjadi pada kelompok usia di atas 64 tahun. Sedangkan keparahan kemiskinan, pengurangan terbesar terjadi pada kelompok usia 46-64 tahun.

Tabel 5.8 Analisis Time Taken to Exit Berdasarkan Usia Kepala Keluarga

\begin{tabular}{|l|l|l|}
\hline \multicolumn{1}{|c|}{ Usia Kepala Keluarga } & \multicolumn{1}{c|}{ Pra ZIS } & \multicolumn{1}{c|}{ Pasca ZIS } \\
\hline $15-45$ tahun & 14,5 tahun & 13,6 tahun \\
\hline $46-64$ tahun & 13,1 tahun & 12 tahun \\
\hline$>64$ tahun & 17,3 tahun & 15,2 tahun \\
\hline
\end{tabular}

Tabel di atas menginformasikan perubahan waktu yang dibutuhkan untuk pengentasan kemiskinan. Sebelum distribusi ZIS, waktu yang dibutuhkan untuk mengentaskan kemiskinan rumah tangga adalah 14,5 tahun untuk kelompok usia 16-45 tahun, 13,1 tahun untuk kelompok usia 46-64 tahun, dan 17,3 tahun untuk kelompok usia di atas 64 tahun. Kinerja ZIS dalam mempercepat waktu pengentasan kemiskinan adalah dari 14,5 tahun menjadi 13,6 tahun untuk kelompok usia 16-45 tahun, dari 13,1 tahun menjadi 12 tahun kelompok usia 4664 tahun. Kinerja ZIS lebih baik terjadi pada kelompok usia di atas 64 tahun dengan mempersingkat waktu pengentasan kemiskinan hingga 2,1 tahun dari 17,3 tahun menjadi 15,2 tahun. Fakta di atas membuktikan bahwa keberadaan OPZ dengan program-programnya mampu memberikan sumbangsih positif bagi akselerasi proses pengentasan kemiskinan.

\subsubsection{Analisa Kemiskinan Berdasarkan Pendidikan Kepala Keluarga}

Pendidikan merupakan variabel yang sangat penting dalam menentukan masa depan masyarakat. Semakin tinggi pendidikan masyarakat, maka diharapkan semakin baik pula kualitas masyarakat.Maju mundur sebuah bangsa dan peradaban, sangat bergantung pada kualitas sistem pendidikannya.Pendidikan diharapkan dapat menjadi media mobilitas vertikal keluarga miskin yang 
efektif.Sehingga pendidikan bisa menjadi sarana efektif untuk mengentaskan kemiskinan, terutama pada jangka panjang. ${ }^{25}$

Penelitian ini membagi pendidikan kepala keluarga ke dalam lima kelompok, yaitu tidak sekolah (tidak pernah mengenyam pendidikan formal), berpendidikan Sekolah Dasar (SD), Sekolah Menengah Pertama (SMP), Sekolah Menengah Atas (SMA), dan diploma/sarjana. Diperkirakan, semakin tinggi pendidikan kepala rumah tangga, maka semakin baik pula kinerja pengentasan kemiskinannya.

Grafik 5.4 Analisa kemiskinan Berdasarkan Pendidikan Kepala Keluarga

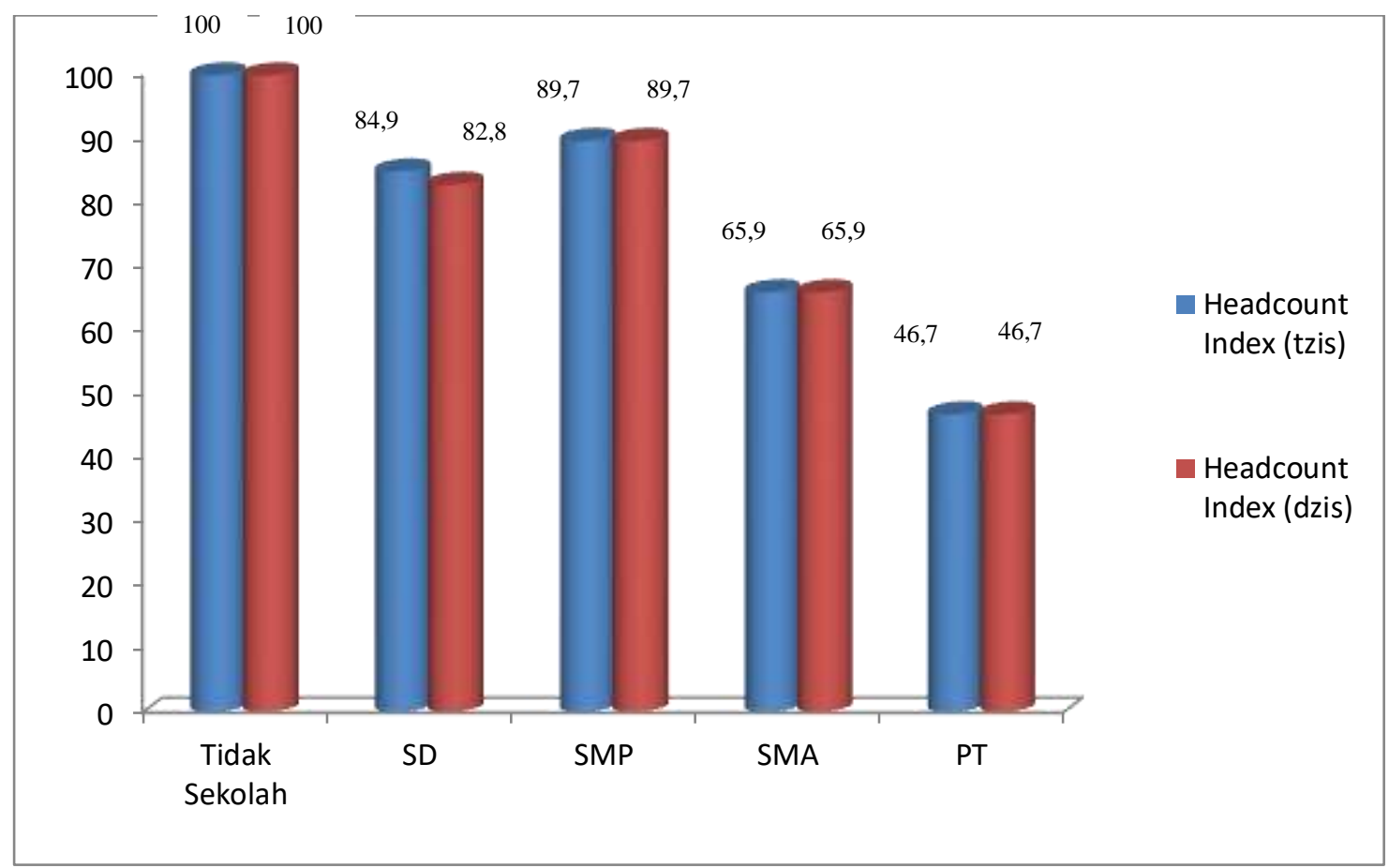

Grafik 5.4 menunjukkan bahwa semakin rendah tingkat pendidikan kepala keluarga maka semakin tinggi pula insiden (jumlah) kemiskinan (kecuali kepala keluarga berpendidikan SMP). Rumah tangga dengan kepala keluarga tidak sekolah memiliki insiden kemiskinan tertinggi. Seluruh rumah tangga dengan kepala keluarga tidak sekolah ini hidup di bawah garis kemiskinan. Pasca distribusi ZIS, insiden kemiskinan pada kelompok ini tetap sama dengan sebelum distribusi ZIS. Artinya, program ZIS kepada kelompok ini ternyata belum mampu mengurangi jumlah kemiskinan yang ada.

25 IZDR 2011, Kajian Empiris Zakat Dalam pengentasan Kemiskinan, Ciputat: IMZ 2011, hlm.34 
Rumah tangga dengan kepala keluarga berpendidikan SD (Sekolah Dasar), jumlah kemiskinannya sangat tinggi mencapai 84,9 persen dari total populasi. Dengan adanya pendistribusian ZIS, insiden kemiskinan kelompok ini dapat dikurangi sebesar 2,53 persen. Artinya, program ZIS yang telah dilakukan memberikan dampak positif terhadap penurunan jumlah rumah tangga miskin dari kelompok yang berpendidikan SD ini, meskipun dampaknya masih kecil.

Kelompok rumah tangga dengan kepala keluarga berpendidikan SMP, memiliki insiden kemiskinan tertinggi kedua setelah kelompok yang tidak pernah sekolah. Hampir seluruh responden rumah tangga dari kelompok ini hidup dibawah garis kemiskinan (89,7 persen). Klompok rumah tangga dengan kepala keluarga berpendidikan SMA memliki insiden kemiskinan sebesar 65,9 persen. Sedangkan Kelompok responden terakhir yaitu rumah tangga dengan kepala keluarga berpendidikan diploma/sarjana memiliki insiden kemiskinan terendah sebesar 46,7 persen. Setelah distribusi ZIS, jumlah kemiskinan pada ketiga kelompok tersebut sama dengan sebelum distribusi ZIS. Fakta ini mengindikasikan bahwa program ZIS belum mampu menurunkan jumlah kemiskinan rumah tangga yang ada.

Tabel 5.9 memperlihatkan semakin rendah pendidikan keluarga maka jurang kemiskinannya semakin dalam (kecuali kelompok PT). Defisit pendapatan kelompok rumah tangga dengan kepala keluarga tidak sekolah dan kepala keluarga berpendidikan SD mencapai lebih 46 persen terhadap garis kemiskinan. Hal serupa terjadi pada keparahan kemiskinan, semakin rendah pendidikan kepala keluarga maka semakin parah kemiskinannya. Temuan ini membuktikan bahwa semakin rendah tingkat pendidikan kepala keluarga akan semakin besar peluang rumah tangga tersebut berada dalam kemiskinan dan beban kemiskinan yang dialami relatif lebih berat.

Yang menarik dari temuan ini adalah kelompok dengan kepala keluarga berpendidikan tinggi (diploma/sarjana) memiliki presentase kedalaman kemiskinan yang hampir sama dengan kelompok kepala keluarga berpendidikan rendah (SD) bahkan tidak pernah sekolah yaitu lebih dari 46 persen.

Tabel 5.9Analisis Kemiskinan Berbasis Pendidikan Kepala Keluarga

\begin{tabular}{|c|c|c|c|c|c|c|c|c|}
\hline \multirow[b]{2}{*}{ Pendidikan } & \multicolumn{2}{|c|}{ P1 } & \multicolumn{2}{|c|}{ I } & \multicolumn{2}{|c|}{ P2 } & \multicolumn{2}{|c|}{ P3 } \\
\hline & TZIS & DZIS & $\begin{array}{c}\text { TZI } \\
\mathrm{S}\end{array}$ & $\begin{array}{c}\text { DZI } \\
\mathrm{S}\end{array}$ & $\begin{array}{c}\text { TZI } \\
\mathrm{S}\end{array}$ & $\begin{array}{c}\text { DZI } \\
\mathrm{S}\end{array}$ & $\begin{array}{c}\text { TZI } \\
\mathrm{S}\end{array}$ & DZIS \\
\hline Tidak Sekolah & $\begin{array}{l}118230 \\
0,00\end{array}$ & $\begin{array}{l}108230 \\
0,00\end{array}$ & $\begin{array}{l}0,46 \\
9\end{array}$ & $\begin{array}{l}0,42 \\
9\end{array}$ & $\begin{array}{l}0,61 \\
4\end{array}$ & $\begin{array}{l}0,57 \\
5\end{array}$ & $\begin{array}{l}0,29 \\
0\end{array}$ & 0,254 \\
\hline $\begin{array}{l}\text { Perubahan } \\
(\%)\end{array}$ & \multicolumn{2}{|l|}{8,46} & \multicolumn{2}{|l|}{8,46} & \multicolumn{2}{|l|}{6,46} & \multicolumn{2}{|c|}{12,33} \\
\hline SD & $\begin{array}{l}107403 \\
6,71\end{array}$ & $\begin{array}{l}100620 \\
2,60\end{array}$ & $\begin{array}{l}0,42 \\
6\end{array}$ & $\begin{array}{l}0,39 \\
9\end{array}$ & $\begin{array}{l}0,46 \\
7\end{array}$ & $\begin{array}{l}0,43 \\
0\end{array}$ & $\begin{array}{l}0,19 \\
4\end{array}$ & 0,168 \\
\hline
\end{tabular}




\begin{tabular}{|c|c|c|c|c|c|c|c|c|}
\hline $\begin{array}{l}\text { Perubahan } \\
(\%)\end{array}$ & \multicolumn{2}{|l|}{6,32} & \multicolumn{2}{|l|}{6,32} & \multicolumn{2}{|c|}{7,92} & \multicolumn{2}{|c|}{13,14} \\
\hline SMP & $\begin{array}{l}903603, \\
85\end{array}$ & $\begin{array}{l}794669, \\
23\end{array}$ & $\begin{array}{l}0,35 \\
9\end{array}$ & $\begin{array}{l}0,31 \\
5\end{array}$ & $\begin{array}{l}0,36 \\
8\end{array}$ & $\begin{array}{l}0,32 \\
6\end{array}$ & $\begin{array}{l}0,14 \\
1\end{array}$ & 0,115 \\
\hline $\begin{array}{l}\text { Perubahan } \\
(\%)\end{array}$ & \multicolumn{2}{|l|}{12,06} & \multicolumn{2}{|c|}{12,06} & \multicolumn{2}{|c|}{11,19} & \multicolumn{2}{|c|}{18,33} \\
\hline SMA & $\begin{array}{l}790377, \\
59\end{array}$ & $\begin{array}{l}704053, \\
45\end{array}$ & $\begin{array}{l}0,31 \\
4\end{array}$ & $\begin{array}{l}0,27 \\
9\end{array}$ & $\begin{array}{l}0,28 \\
1\end{array}$ & $\begin{array}{l}0,25 \\
8\end{array}$ & $\begin{array}{l}0,09 \\
1\end{array}$ & 0,078 \\
\hline $\begin{array}{l}\text { Perubahan } \\
(\%)\end{array}$ & \multicolumn{2}{|l|}{10,92} & \multicolumn{2}{|c|}{10,92} & \multicolumn{2}{|c|}{8,03} & \multicolumn{2}{|c|}{14,57} \\
\hline $\begin{array}{l}\text { Diploma/ } \\
\text { Sarjana }\end{array}$ & $\begin{array}{l}117621 \\
4,29\end{array}$ & $\begin{array}{l}110374 \\
2,86\end{array}$ & $\begin{array}{l}0,46 \\
7\end{array}$ & $\begin{array}{l}0,43 \\
8\end{array}$ & $\begin{array}{l}0,26 \\
2\end{array}$ & \begin{tabular}{|l|}
0,25 \\
0
\end{tabular} & $\begin{array}{l}0,11 \\
6\end{array}$ & 0,105 \\
\hline $\begin{array}{l}\text { Perubahan } \\
(\%)\end{array}$ & \multicolumn{2}{|l|}{6,16} & \multicolumn{2}{|l|}{6,16} & \multicolumn{2}{|c|}{4,75} & \multicolumn{2}{|l|}{9,77} \\
\hline
\end{tabular}

Meskipun pendayagunaan ZIS oleh lembaga zakat terkait belum dapat mengurangi insiden kemiskinan di semua tingkat pendidikan dengan pengecualian kelompok berpendidikan SD (grafik 5.4), namun demikian pendayagunaan ZIS berdampak positif dalam menurunkan tingkat kedalaman kemiskinan dan tingkat keparahan kemiskinan di semua tingkat pendidikan .

Kinerja program ZIS dalam mempersempit jurang kemiskinan pada kelompok rumah tangga dengan kepala keluarga yang tidak pernah sekolah cukup baik. Baik indeks poverty gap maupun income gap keduanya menunjukkan penurunan. Defisit rata-rata pendapatan kelompok ini dengan garis kemiskinan dapat dikurangi dari Rp 1182300,00 men jadi 1082300,00. Demikian pula dengan nilai income gap pasca ZIS $(0,469)$ yang nilainya lebih kecil daripada income gap prazakat $(0,429)$.Penurunan rata-rata dari kedua rasio ini mencapai 8,46 persen. Implikasi positif dari ZIS juga terjadi pada tingkat keparahan kemiskinan. Indeks sen dan indeks FGT pasca ZIS menunjukkan adanya reduksi nilai masing-masing sebesar 6,46 persen dan 12,33 persen.

Untuk kelompok yang kedua, yaitu kelompok rumah tangga dengan kepala keluarga berpendidikan SD, jarak antara rata-rata pendapatan rumah tangga miskin dengan garis kemiskinan juga dapat dikurangi dengan adanya ZIS, yaitu dari Rp 1074036,71 menjadi Rp 1006202,60. Demikian pula dengan presentase kesenjangan pendapatan rumah tangga miskin yang dapat diturunkan dari 0,426 menjadi 0,399. Prosentase penurunan kedua indeks tersebut sebesar 6,32 persen. Temuan ini mengisyaratkan bahwa jurang kemiskinan pada kelompok rumah tangga dengan kepala keluarga berpendidikan SD ini dapat 
dipersempit melalui distribusi ZIS. Hal yang sama juga terjadi pada keparahan kemiskinan di mana program ZIS berdampak positif dengan menurunkan nilai indeks Sen sebesar 7,92 persen dan indeks FGT sebesar 13,14 persen. Fakta ini menunjukkan peran positif ZIS ini dalam mengurangi beban keparahan kemiskinan yang diderita oleh kelompok responden ini.

Kelompok yang ketiga yaitu rumah tangga dengan kepala keluarga berpendidikan SMP. Tingkat kedalaman kemiskinan dan tingkat keparahan kemiskinan pada kelompok ini mengalami penurunan tertinggi dibanding kelompok lainnya. Kinerja ZIS dalam memperkecil defisit pendapatan dengan garis kemiskinan pada kelompok ini sangatlah baik yaitu sebesar 12,06 persen dari Rp 903603,85 menjadi Rp 794669,23. Demikian pula dengan prosentase kesenjangan pendapatan rumah tangga miskin yang turun dari 0,359 menjadi 0,315 . Kinerja positif program ZIS dalam menurunkan tingkat keparahan kemiskinan pada kelompok ini juga sangat baik yaitu sebesar 11,19 persen untuk indeks Sen dan 18,33 persen untuk indeks FGT.

Kelompok yang keempat yaitu rumah tangga dengan kepala keluarga berpendidikan SMA memiliki jurang kemiskinan terendah dari kelompokkelompok lainnya. Kelompok ini juga memiliki Penurunan tingkat kedalaman kemiskinan dan tingkat keparahan kemiskinan tertinggi kedua setelah kelompok berpendidikan SD. Untuk tingkat kedalaman kemiskinan, selisih antara garis kemiskinan dengan rata-rata pendapatan rumah tangga miskin pasca ZIS dapat diperkecil dari Rp 790377,59 menjadi Rp 704053,45. Adapun prosentase kesenjangan pendapatan rumah tangga miskin dapat diturunkan dari 0,314 menjadi 0,279. Reduksi nilai kedua indeks tersebut mencapai 10,92 persen. Demikian pula halnya dengan tingkat keparahan kemiskinan mustahik di mana nilai indeks Sen dan inseks FGT mengalami penurunan masing-masing sebesar 8,03 persen dan 14,57 persen.

Kelompok yang terakhir yaitu kelompok rumah tangga dengan kepala keluarga berpendidikan diploma/sarjana. Yang menarik adalah meskipun kelompok ini berpendidikan tinggi, namun tingkat kedalaman kemiskinan pada kelompok ini adalah tertinggi kedua setelah kelompok tidak sekolah.

Distribusi ZIS pada kelompok ini memiliki dampak positif terhadap peneurunan tingkat kedalaman kemiskinan meskipun presentase penurunannya kecil. Defisit pendapatan rumah tangga miskin dengan garis kemiskinan dapat dikurangi dari Rp 1176214,29 menjadi Rp 1103742,86, atau turun sebesar 6,16 persen. Demikian pula dengan rata-rata kesenjangan pendapatan per rumah tangga yang berkurang dengan prosentase yang sama. Fakta yang serupa juga terjadi pada tingkat keparahan kemiskinan di mana indeks Sen dan FGT pasca ZIS menunjukkan adanya penurunan masing-masing sebesar 4,75 persen dan 9,77 persen. Hasil ini mengkonfirmasi peran positif ZIS dalam meringankan 
tingkat keparahan kemiskinan mustahik, sehingga kondisi kelompok responden ini menjadi lebih baik.

Dari data-data di atas dapat disimpulkan bahwa distibusi ZIS memiliki implikasi positif terhadap pengurangan jurang kemiskinan dan keparahankemiskinan di semua kelompok pendidikan dengan presentase penurunan terbesar terjadi pada kelompok rumah tangga dengan kepala keluarga berpendidikan SMP.

Program ZIS juga memiliki implikasi positif dalam mempersingkat waktu pengentasan kemiskinan. Tabel 5.10 berikut memaparkan kisaran waktu yang dibutuhkan rumah tangga miskin untuk keluar dari garis kemiskinan pra dan pasca ZIS.

Tabel 5.10 Analisis Time Taken to Exit

\begin{tabular}{|l|c|c|}
\hline \multicolumn{1}{|c|}{ Pendidikan } & Pra ZIS & Pasca ZIS \\
\hline Tidak Sekolah & 21 & 18,3 \\
\hline SD & 15,7 & 14,2 \\
\hline SMP & 13,4 & 12,3 \\
\hline SMA & 11,2 & 10,7 \\
\hline Diploma/Sarjana & 11,7 & 11,2 \\
\hline
\end{tabular}

Dari tabel di atas dapat dianalisa bahwa semakin rendah pendidikan kepala keluarga, maka semakin lama waktu yang mereka butuhkan untuk keluar dari kemiskinan (kecuali pada kelompok diploma/sarjana). Temuan ini membuktikan bahwa pendidikan adalah akses penting yang dapat memutus kemiskinan seseorang.pendidikan yang tinggi membuat seseorang memiliki kesempatan lebih besar untuk bersaing dalam dunia usaha dan pekerjaan.

Kelompok rumah tangga dengan kepala keluarga tidak pernah sekolah memerlukan waktu paling lama di antara kelompok lainnya, yaitu 21 tahun. Akan tetapi, dengan keberadaan ZIS maka waktu pengentasan kemiskinan tersebut dapat dipercepat 2,7 tahun menjadi 18,3 tahun. Hal yang sama juga terjadi pada kelompok rumah tangga dengan kepala keluarga berpendidikan SD, SMP, SMA, dan diploma/sarjana. Masing-masing waktu pengentasannya menjadi lebih cepat 1,5 tahun untuk SD, 1,1 tahun untuk SMP, 0,5 tahun untuk SMA, dan 5 bulan untuk diploma/sarjana.

Dari fakta di atas, dapat disimpulkan bahwa keberadaan program ZIS dapat mempercepat proses pengentasan kemiskinan mustahik di semua level 
pendidikan. Percepatan waktu pengentasan paling tinggi terjadi pada kelompok keluarga dengan kepala keluarga yang tidak pernah sekolah. Sementara percepatan waktu pengentasan paling rendah terjadi pada kelompok keluarga dengan kepala keluarga berpendidikan diploma/sarjana.

\subsubsection{Analisa Kemiskinan Berdasarkan Pekerjaan Kepala Keluarga}

Kesempatan kerja merupakan variabel yang sangat penting dalam menentukan kebutuhan kehidupan dalam masyarakat, termasuk dalam mempengaruhi tingkat kemiskinan dan kesejahteraan. Semakin tinggi kesempatan kerja yang dimiliki masyarakat, akan semakin tinggi pula kesempatan untuk meningkatkan kesejahteraan masyarakat. Demikian juga sebaliknya, menurunnya kesempatan kerja dapat meningkatkan angka kemiskinan masyarakat. Karena itu, menurunkan angka pengangguran merupakan salah satu target kebijakan ekonomi dunia.termasuk di Indonesia. ${ }^{26}$

Penelitian ini membagi jenis pekerjaan kepala rumah tangga mustabik kedalam beberapa katagori.Yaitu tidak bekerja, ibu rumah tangga, karyawan/pegawai/pensiunan, pedagang mikro/wiraswasta, tenaga usaha jasa transportasi, buruh dan tenaga kebersihan, petani, dan lainnya. Grafik 5.5 berikut memperlihatkan persentase insiden kemiskinan sebelum dan setelah distribusi ZIS.

Grafik 5.5 Analisa Kemiskinan Berdasarkan Pekerjaan Kepala Keluarga

100100

$100100 \quad 100100$

100

26 IZDR 2011, Kajian Empiris Zakat Dalam pengentasan Kemiskinan, Ciputat: IMZ 2011,hlm.41-41 


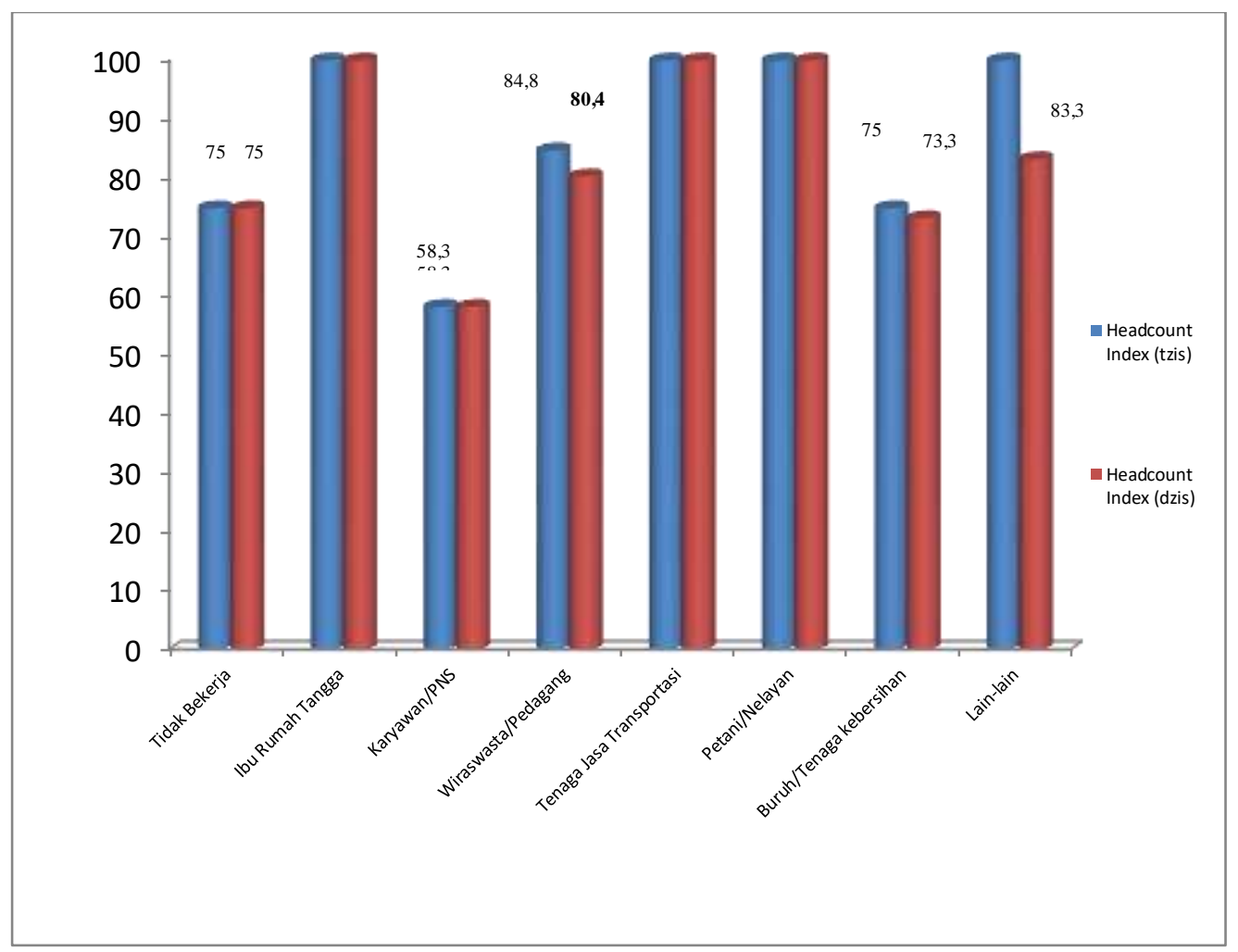

Dari grafik di atas terlihat bahwa ada empat kelompok rumah tangga yang memiliki presentase insiden kemiskinan 100 persen. Keempat kelompok tersebut adalah rumah tangga dengan kepala keluarga ibu rumah tangga, rumah tangga dengan kepala keluarga berprofesi sebagai tenaga usaha jasa transportasi, rumah tangga dengan kepala keluarga beprofesi petani/nelayan dan rumah tangga dengan kepala keluarga beprofesi lain-lain. Kelompok lain-lain ini terdiri dari mereka yang bekerja di luar kategori yang ada seperti ustad/penceramah, marbot masjid, guru ngaji dan tukang pijit. Presentase insiden kemiskinan tertinggi kedua adalah rumah tangga dengan kepala keluarga berprofesi sebagai pedagang mikro/wiraswasta sebesar 84,8 persen. Kemudian disusul oleh kelompok rumah tangga dengan kepala keluarga tidak bekerja dan kelompok rumah tangga dengan kepala keluarga berprofesi sebagai buruh/tenaga kebersihan masing-masing sebesar 75,0 persen. Kelompok dengan presentase insiden kemiskinan terendah adalah kelompok rumah tangga yang berprofesi karyawan/PNS/pensiunan.

Tabel 5.11 Analisa Kemiskinan Berdasarkan Pekerjaan Kepala Rumah Tangga

\begin{tabular}{|l|l|l|l|l|l|l|l|l|}
\hline \multirow{2}{*}{ Jenis Pekerjaan } & \multicolumn{2}{|l|}{ P1 } & \multicolumn{2}{l|}{ I } & P2 & \multicolumn{2}{l|}{ P3 } \\
\cline { 2 - 7 } & TZIS & DZIS & $\begin{array}{l}\text { TZI } \\
\text { S }\end{array}$ & $\begin{array}{l}\text { DZI } \\
\text { S }\end{array}$ & $\begin{array}{l}\text { TZI } \\
\text { S }\end{array}$ & $\begin{array}{l}\text { DZI } \\
\text { S }\end{array}$ & $\begin{array}{l}\text { TZI } \\
\text { S }\end{array}$ & $\begin{array}{l}\text { DZI } \\
\text { S }\end{array}$ \\
\hline
\end{tabular}




\begin{tabular}{|c|c|c|c|c|c|c|c|c|}
\hline Tidak Bekerja & $\begin{array}{l}1123255, \\
56\end{array}$ & $\begin{array}{l}103766 \\
6,68\end{array}$ & $\begin{array}{l}0,44 \\
6\end{array}$ & $\begin{array}{l}0,41 \\
2\end{array}$ & $\begin{array}{l}0,42 \\
8\end{array}$ & $\begin{array}{l}0,40 \\
0\end{array}$ & $\begin{array}{l}0,18 \\
6\end{array}$ & $\begin{array}{l}0,16 \\
2\end{array}$ \\
\hline Perubahan $(\%)$ & \multicolumn{2}{|l|}{7,620} & \multicolumn{2}{|l|}{7,62} & \multicolumn{2}{|l|}{6,55} & \multicolumn{2}{|c|}{12,61} \\
\hline Ibu Rumah Tangga & $\begin{array}{l}956300,0 \\
0\end{array}$ & $\begin{array}{l}815300, \\
00\end{array}$ & $\begin{array}{l}0,37 \\
9\end{array}$ & $\begin{array}{l}0,32 \\
4\end{array}$ & $\begin{array}{l}0,53 \\
6\end{array}$ & $\begin{array}{l}0,48 \\
2\end{array}$ & $\begin{array}{l}0,22 \\
3\end{array}$ & $\begin{array}{l}0,18 \\
6\end{array}$ \\
\hline Perubahan (\%) & \multicolumn{2}{|l|}{14,744} & \multicolumn{2}{|c|}{14,74} & \multicolumn{2}{|c|}{10,09} & \multicolumn{2}{|c|}{16,75} \\
\hline $\begin{array}{l}\text { Karyawan/PNS/ } \\
\text { Pensiunan }\end{array}$ & $\begin{array}{l}939323,8 \\
1\end{array}$ & $\begin{array}{l}853514, \\
29\end{array}$ & $\begin{array}{l}0,37 \\
3\end{array}$ & $\begin{array}{l}0,33 \\
9\end{array}$ & $\begin{array}{l}0,27 \\
9\end{array}$ & $\begin{array}{l}0,25 \\
8\end{array}$ & $\begin{array}{l}0,10 \\
1\end{array}$ & $\begin{array}{l}0,08 \\
7\end{array}$ \\
\hline Perubahan $(\%)$ & \multicolumn{2}{|l|}{9,135} & \multicolumn{2}{|l|}{9,13} & \multicolumn{2}{|l|}{7,40} & \multicolumn{2}{|c|}{13,89} \\
\hline $\begin{array}{l}\text { Wiraswasta/ } \\
\text { Pedagang }\end{array}$ & $\begin{array}{l}880164,1 \\
0\end{array}$ & $\begin{array}{l}816464, \\
86\end{array}$ & $\begin{array}{l}0,34 \\
9\end{array}$ & $\begin{array}{l}0,32 \\
4\end{array}$ & $\begin{array}{l}0,41 \\
2\end{array}$ & $\begin{array}{l}0,36 \\
7\end{array}$ & $\begin{array}{l}0,15 \\
3\end{array}$ & $\begin{array}{l}0,12 \\
8\end{array}$ \\
\hline Perubahan $(\%)$ & \multicolumn{2}{|l|}{7,237} & \multicolumn{2}{|l|}{7,24} & \multicolumn{2}{|c|}{10,97} & \multicolumn{2}{|c|}{16,39} \\
\hline $\begin{array}{l}\text { Tenaga Usaha Jasa } \\
\text { Transportasi }\end{array}$ & $\begin{array}{l}906807,1 \\
4\end{array}$ & $\begin{array}{l}822257, \\
14\end{array}$ & $\begin{array}{l}1,00 \\
8\end{array}$ & $\begin{array}{l}0,91 \\
4\end{array}$ & $\begin{array}{l}1,00 \\
6\end{array}$ & $\begin{array}{l}0,92 \\
7\end{array}$ & $\begin{array}{l}0,16 \\
2\end{array}$ & $\begin{array}{l}0,14 \\
0\end{array}$ \\
\hline Perubahan (\%) & \multicolumn{2}{|l|}{9,324} & \multicolumn{2}{|l|}{9,32} & \multicolumn{2}{|l|}{7,89} & \multicolumn{2}{|c|}{13,53} \\
\hline $\begin{array}{l}\text { Buruh/Tenaga } \\
\text { Kebersihan }\end{array}$ & $\begin{array}{l}1113794, \\
44\end{array}$ & $\begin{array}{l}102602 \\
1,59\end{array}$ & $\begin{array}{l}0,44 \\
2\end{array}$ & $\begin{array}{l}0,40 \\
7\end{array}$ & $\begin{array}{l}0,41 \\
0\end{array}$ & $\begin{array}{l}0,37 \\
7\end{array}$ & $\begin{array}{l}0,17 \\
2\end{array}$ & $\begin{array}{l}0,14 \\
7\end{array}$ \\
\hline Perubahan $(\%)$ & \multicolumn{2}{|l|}{7,881} & \multicolumn{2}{|l|}{7,88} & \multicolumn{2}{|l|}{8,03} & \multicolumn{2}{|c|}{14,21} \\
\hline Petani/Nelayan & $\begin{array}{l}1024357, \\
14\end{array}$ & $\begin{array}{l}889928, \\
57\end{array}$ & $\begin{array}{l}0,40 \\
6\end{array}$ & $\begin{array}{l}0,35 \\
3\end{array}$ & $\begin{array}{l}0,60 \\
4\end{array}$ & $\begin{array}{l}0,45 \\
6\end{array}$ & $\begin{array}{l}0,20 \\
6\end{array}$ & $\begin{array}{l}0,16 \\
0\end{array}$ \\
\hline Perubahan $(\%)$ & \multicolumn{2}{|l|}{13,123} & \multicolumn{2}{|c|}{13,12} & \multicolumn{2}{|c|}{24,56} & \multicolumn{2}{|c|}{22,15} \\
\hline Lainnya & $\begin{array}{l}1079833, \\
33\end{array}$ & $\begin{array}{l}839140, \\
00\end{array}$ & $\begin{array}{l}0,42 \\
9\end{array}$ & $\begin{array}{l}0,33 \\
3\end{array}$ & $\begin{array}{l}0,51 \\
4\end{array}$ & $\begin{array}{l}0,34 \\
8\end{array}$ & $\begin{array}{l}0,20 \\
9\end{array}$ & $\begin{array}{l}0,11 \\
2\end{array}$ \\
\hline Perubahan $(\%)$ & \multicolumn{2}{|l|}{22,29} & \multicolumn{2}{|c|}{22,29} & \multicolumn{2}{|c|}{32,19} & \multicolumn{2}{|c|}{46,31} \\
\hline
\end{tabular}

Berdasarkan grafik dan tabel di atas, terlihat bahwa distribusi ZIS kepada kelompok rumah tangga yang dipimpin oleh kepala keluarga yang tidak bekerja belum memiliki dampak positif dalam mengurangi insiden kemiskinan. Presentase insiden kemiskinan pada kelompok ini pra dan pasca distribusi ZIS tetap sama, yaitu 75 persen.

Namun demikian, dari sisi kedalaman kemiskinan, distribusi ZIS memberikan dampak positif yang diindikasikan dengan turunnya nilai poverty gap dan income gap sebesar 7,62 persen. Ini mengindikasikan semakin dekatnya jarak antara pendapatan rata-rata rumah tangga miskin dengan garis kemiskinan. 
Demikian pula halnya dengan tingkat keparahan kemiskinan yang dapat direduksi setelah indeks Sen dan indeks FGT menunjukkan penurunan masing-masing sebesar 6,55 persen dan 12,61 persen.

Kelompok responden selanjutnya adalah rumah tangga mustahik dengan kepala keluarga ibu rumah tangga, yang belum memiliki pekerjaan tetap. Program ZIS yang dilakukan terhadap kelompok ini ternyata belum mampu mengurangi jumlah kemiskinan. Presentase insiden kemiskinan pada kelompok ini tetap sama dengan sebelum ZIS didistribusikan, yaitu 100 persen.

Namun demikian, program ZIS yang ada memberikan dampak positif terhadap penurunan tingkat kedalaman kemiskinan dan tingkat keparahan kemiskinan. Kedua nilai indeks poverty gap dan income gap pasca ZIS mengalami penurunan sebesar 14,74 persen. Demikian pula halnya dengan indeks Sen dan indeks FGT pasca ZIS yang mengalami reduksi masing-masing sebesar 10,09 persen dan 16,75 persen. Hal ini menunjukkan bahwa kondisi kelompok responden ini menjadi lebih baik dengan adanya ZIS.

Kelompok responden yang ketiga adalah rumah tangga mustahik dengan kepala keluarg yang bekerja sebagai karyawan/pegawai/pensiunan. Keberadaan program ZIS yang ditujukan kepada kelompok ini belum mampu mereduksi jumlah kemiskinan mustahik. Presentase jumlah kemiskinan pasca ZIS pada kelompok tetap sama 58,3 persen.

Sedangkan dari sisi kedalaman kemiskinan, keberadaan ZIS menunjukkan kinerja yang positif yang diindikasikan dengan berkurangnya nilai Indeks kesenjangan kemiskinan dan indeks kesenjangan pendapatan masing-masing sebesar 9,13 persen. Fakta serupa juga dapat dianalisa dari tingkat keparahan kemiskinan. Indeks Sen dan indeks FGT pasca ZIS mengalami penurunan masing-masing sebesar 7,40 persen dan 13,89 persen.Fakta ini menunjukkan bahwa pengelolaan ZIS yang terorganisir oleh lembaga yang amanah mampu meringankan beban kemiskinan rumah tangga mustahik.

Kelompok rumah tangga yang keempat adalah kelompok rumah tangga dengan kepala keluarga yang bekerja sebagai pedagang mikro/wiraswasta. Keberadaan program ZIS pada kelompok ini terbukti mampu mengurangi jumlah kemiskinan mustahik. Namun prosentase penurunannya masih tergolong kecil, yaitu hanya 5,13 persen.

Dari sisi kedalaman kemiskinan, keberadaan ZIS juga memberikan implikasi yang positif terhadap kelompok responden ini. Penurunan poverty gap dan income gapsebesar 7,24 persen ini mengindikasikan semakin dekatnya jarak antara pendapatan rata-rata rumah tangga miskin dengan garis kemiskinan. Sedangkan dari sisi keparahan kemiskinan, kinerja ZIS dalam mereduksi tingkat keparahan kemiskinan pada kelompok ini sangatlah baik di mana indeks Sen dan 
indeks FGT pasca ZIS mengalami reduksi masing-masing sebesar 10,97 persen dan 16,39 persen.

Kelompok responden kelima adalah kelompok rumah tangga dengan kepala keluarga yang bekerja di sektor jasa transportasi seperti sopir angkutan umum, ojek, dan penarik becak. Program ZIS untuk kelompok ini belum mampu menurunkan jumlah kemiskinan mustahik. Presentase insiden kemiskinan pasca ZIS tetap sama yaitu sebesar 100 persen.

Adapun jika ditinjau dari tingkat kedalaman kemiskinan dan tingkat keparahan kemiskinan, program ZIS memiliki dampak yang positif pada kelompok responden ini. Nilai indeks poverty gap dan income gap pasca ZIS mengalami penurunan masing-masing sebesar 9,32 persen. Demikian pula halnya dengan indeks Sen dan indeks FGT pasca ZIS yang mengalami reduksi masingmasing sebesar 7,93 persen dan 13,53 persen.

Selanjutnya, kelompok responden keenam, yaitu kelompok rumah tangga dengan kepala keluarga yang bekerja sebagai buruh atau tenaga kebersihan. Pada kelompok ini, dengan adanya program ZIS, jumlah rumah tangga miskin berkurang sedikit sebesar 2,22 persen dari 0,750 menjadi 0,733. Jurang kemiskinan juga semakin menyempit dari 0,442 menjadi 0,407 (prosentase penurunan mencapai 7,88 persen). Hal ini menunjukkan program ZIS terbukti mampu mengurangi tingkat kedalaman kemiskinan pada kelompok ini.

Hal serupa terjadi pada indeks keparahan kemiskinan yang turun sebesar 8,03 persen untuk indeks Sen dan 14,21 persen untuk indeks FGT. Dengan demikian, pendayagunaan ZIS oleh OPZ berhasil mengurangi beban kemiskinan di kelompok rumah tangga yang dipimpin oleh kepala keluarga yang bekerja sebagai buruh atau tenaga kebersihan.

Kelompok responden ketujuh adalah kelompok rumah tangga dengan kepala keluarga yang bekerja sebagai petani atau nelayan. Program ZIS untuk kelompok ini belum mampu menurunkan jumlah kemiskinan mustahik. Jumlah kemiskinan sebelum dan setelah ZIS tetap sama yaitu sebesar 100 persen.

Namun demikian, program ZIS berimplikasi positif pada pengurangan tingkat kedalaman kemiskinan. Jurang kemiskinan kelompok petani/nelayan ini pra ZISadalah Rp 1024357,14. Sedangkan pasca ZIS jurang kemiskinan tersebut berkurang menjadi Rp 889928,57 atau turun sebesar Rp 134428,57 dari angka sebelumnya. Nilai income gap index ikut turun dari 0,406 menjadi 0,353. Prosentase penurunan kedua indeks di atas adalah mencapai 13,12 persen.

Program ZIS juga berhasil menurunkan tingkat keparahan kemiskinan secara signifikan. Nilai indeks Sen dan indeks FGT pasca ZIS mengalami penurunan masing-masing sebesar 24,56 persen dan 22,15. Berdasarkan temuan empiris ini, maka dapat dikatakan bahwa program ZIS memiliki peran positif 
dalam mengurangi beban kemiskinan rumah tangga dengan kepala keluarga berprofesi sebagai petani/nelayan ini.

Kelompok responden yang terakhir adalah kelompok rumah tangga dengan kepala keluarga yang bekerja disektor pekerjaan selain yang disebutkan sebelumnya. Kelompok lain-lain ini terdiri dari mereka yang bekerja di luar kategori yang ada seperti ustad/penceramah, marbot masjid, guru ngaji, dan tukang pijit. Melalui pendayagunaan ZIS oleh OPZ, insiden kemiskinan pada kelompok ini berhasil diturunkan sebesar 16,67 persen dari presentase 100 persen menjadi 83,3 persen.

Sedangkan dari sisi kedalaman kemiskinan, keberadaan ZIS juga memberikan implikasi yang positif terhadap kelompok responden ini. Penurunan poverty gap dan income gap sebesar 22,29 persen ini mengindikasikan semakin dekatnya jarak antara pendapatan rata-rata rumah tangga miskin dengan garis kemiskinan. Hasil positif serupa jugaterjadi pada tingkat keparahan kemiskinan. Hasil empiris indeks Sen dan indeks FGT pasca ZIS mengalami reduksi yang sangat signifikan masing-masing sebesar 32,19 persen dan 46,31 persen. Ini merupakan bukti empiris yang sangat valid tentang peran positif ZIS dalam mengurangi tingkat keparahan kemiskinan.

Dari temuan fakta-fakta di atas dapat disimpulkan bahwa program pendayagunaan ZIS yang telah dilakukan mampu mereduksi insiden kemiskinan (poverty incidence) pada rumah tangga dengan kepala keluarga yang berprofesi pedagang/wiraswasta, kepala keluarga yang berprofesi buruh/tenaga kebersihan, dan kepala keluarga yang berprofesi lain-lain. Presentase penurunan terbesar terjadi pada kepala keluarga yang berprofesi lain-lain yaitu sebesar 16,67 perswen. Sedangkan dari sisi kedalaman kemiskinan dan keparahan kemiskinan, program pendayagunaan ZIS memperlihatkan kinerja positif di semua kelompok pekerjaan kepala keluarga. Penurunan terbesar terjadi pada kelompok rumah tangga dengan kepala keluarga yang berprofesi lain-lain.

Tabel 5.12 memperlihatkan dampak positif ZIS dalam mempersingkat waktu pengentasan kemiskinan mustahik. Program ZIS dapat mempersingkat waktu pengentasan kemiskinan sebesar 1,5 tahun untuk kelompok kepala keluarga tidak bekerja, 2,1 tahun untuk kelompok kepala keluarga ibu rumah tangga, 0,5 tahun untuk kelompok kepala keluarga yang bekerja sebagai karyawan/PNS/pensiunan, 1,5 tahun untuk kelompok kepala keluarga yang bekerja sebagai pedagann/wiraswasta, 9 bulan untuk kelompok kepala yang bekerja di sektor jasa transportasi, 8 bulan untuk kelompok kepala keluarga yang bekerja sebagai buruh/tenaga kebersihan, 1,7 tahun untuk kelompok kepala keluarga yang bekerja sebagai petani/nelayan, 1,6 tahun untuk kelompok kepala keluarga yang bekerja sektor pekerjaan selain yang disebutkan sebelumnya.

Tabel 5.12 Analisis Time Taken to Exit 


\begin{tabular}{|l|c|c|}
\hline \multicolumn{1}{|c|}{ Pekerjaan } & $\begin{array}{c}\text { Pra ZIS } \\
\%\end{array}$ & $\begin{array}{c}\text { Pasca ZIS } \\
\%\end{array}$ \\
\hline Tidak Bekerja & 15,8 & 14,3 \\
\hline Ibu Rumah Tangga & 18,5 & 16,4 \\
\hline Karyawan/PNS/Pensiunan & 11,3 & 10,7 \\
\hline Wiraswasta/Pedagang & 14,7 & 13,2 \\
\hline Tenaga Usaha /Jasa Transportasi & 14,4 & 13,6 \\
\hline Buruh/Tenaga Kebersihan & 14,3 & 13,6 \\
\hline Petani/Nelayan & 15,7 & 14 \\
\hline Pekerjaan Lainnya & 15,6 & 14 \\
\hline
\end{tabular}

Fakta di atas membuktikan bahwa keberadaan OPZ dengan programprogramnya mampu memberikan sumbangsih positif bagi percepatan pengentasan kemiskinan.

\subsubsection{Analisa Kemiskinan Berdasarkan Ukuran Anggota Rumah Tangga}

Ukuran rumah tangga juga merupakan variabel yang dapat menentukan kesejahteraan rumah tangga. Banyak studi menegaskan bahwa banyaknya anggota keluarga dapat mempengaruhi kemiskinan, meski tidak linier. Secara umum, dapat dimungkinkan bahwa rumah tangga yang banyak jumlah anggota keluarganya, maka beban kehidupan yang ditanggung semakin berat, sehingga rumah tangga tersebut menjadi rentan pada kemiskinan. ${ }^{27}$

Dalam penelitian ini, rumah tangga dibagi kedalam tiga kelompok berdasarkan ukuran atau banyaknya jumlah anggota keluarga.Yaitu, rumah tangga dengan jumlah anggota 1-3 orang, 4-6 orang dan 7 orang atau lebih. Pada Tabel 5.11 berikut ini akan dipaparkan tentang kinerja zakat dalam mengurangi kemiskinan ditinjau berdasarkan ukuran rumah tangga.

Grafik 5.6 Analisa kemiskinan Berdasarkan Ukuran Anggota

${ }^{27}$ IZDR 2011, hal.45 


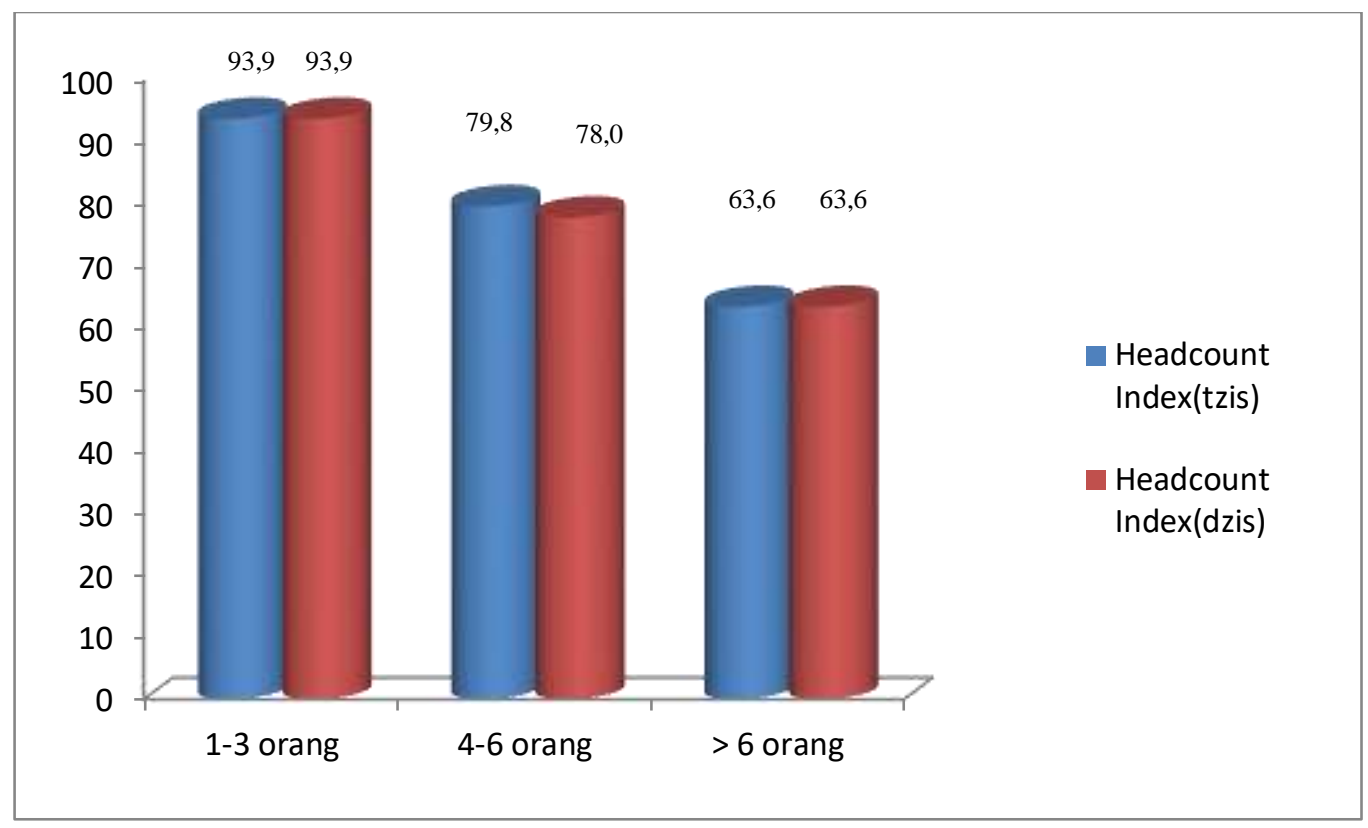

Grafik 5.6 memperlihatkan tingkat insiden kemiskinan sebelum dan setelah distribusi ZIS. Dari grafik terlihat bahwa rumah tangga dengan anggota keluarga yang lebih sedikit justru memiliki insiden kemiskinan lebih tinggi. Rumah tangga dengan anggota keluarga 1-3 orang memiliki presentase insiden kemiskinan tertinggi. Seluruh responden dari kelompok ini hidup di bawah garis kemiskinan. Lalu disusul oleh rumah tangga dengan anggota keluarga dengan ukuran keluarga 4-6 orang yang memiliki presentase insiden kemiskinan sebesar 79,8 persen. Presentase insiden kemiskinan terendah dimiliki oleh rumah tangga yang terdiri lebih dari 6 orang.

Jika dianalisa lebih dalam, rumah tangga dengan anggota keluarga yang lebih banyak memiliki insiden kemiskinan yang lebih rendah diduga karena usia rumah tangga mereka sudah lama. Pada umumnya mereka memiliki anak-anak yang sebagiannya sudah dewasa dan telah memiliki pekerjaan. Dengan kata lain, anak-anak yang telah memiliki pekerjaan tersebut ikut membantu perekonomian keluarga. Sebaliknya, rumah tangga dengan jumlah anggota keluarga lebih kecil (1-3 orang) memiliki insiden kemiskinan lebih tinggi diduga karena kepala keluarga adalah satu-satunya yang bekerja untuk memenuhi kebutuhan keluarganya. Anak-anak mereka masih kecil sehingga belum bisa membantu kepala keluarga dalam mencari nafkah.

Tabel 5.13 Analisis Kemiskinan Berdasarkan Ukuran Anggota Keluarga

\begin{tabular}{|l|l|l|l|l|}
\hline $\begin{array}{l}\text { Indika } \\
\text { tor }\end{array}$ & 1-3 Orang & 4-6 Orang & $\begin{array}{l}7 \text { Orang } \\
/ \text { Lebih }\end{array}$ & $\begin{array}{l}\text { Prosentase } \\
\text { perubahan (\%) }\end{array}$ \\
\hline
\end{tabular}




\begin{tabular}{|c|c|c|c|c|c|c|c|c|c|}
\hline $\begin{array}{l}\text { Kemis } \\
\text { ki } \\
\text { nan }\end{array}$ & TZIS & DZIS & TZIS & DZIS & $\begin{array}{l}\text { TZI } \\
\mathrm{S}\end{array}$ & $\begin{array}{l}\text { DZI } \\
\text { S }\end{array}$ & $\begin{array}{l}\text { DZI } \\
\text { S }\end{array}$ & $\begin{array}{l}\text { DZI } \\
\text { S }\end{array}$ & $\begin{array}{l}\text { DZI } \\
\text { S }\end{array}$ \\
\hline $\mathrm{P} 1$ & $\begin{array}{l}142104 \\
8,39\end{array}$ & $\begin{array}{l}130853 \\
8,71\end{array}$ & $\begin{array}{l}967177, \\
59\end{array}$ & $\begin{array}{l}899352, \\
35\end{array}$ & $\begin{array}{l}6147 \\
00\end{array}$ & $\begin{array}{l}5244 \\
50\end{array}$ & 7,92 & 7,01 & $\begin{array}{l}14,6 \\
8\end{array}$ \\
\hline I & 0,564 & 0,519 & 0,384 & 0,357 & $\begin{array}{l}0,24 \\
4\end{array}$ & $\begin{array}{l}0,20 \\
8\end{array}$ & 7,92 & 7,01 & $\begin{array}{l}14,6 \\
8\end{array}$ \\
\hline P2 & 0,621 & 0,579 & 0,398 & 0,367 & $\begin{array}{l}0,20 \\
4\end{array}$ & $\begin{array}{l}0,18 \\
2\end{array}$ & 6,74 & 7,77 & $\begin{array}{l}10,7 \\
0\end{array}$ \\
\hline P3 & 0,323 & 0,282 & 0,150 & 0,130 & $\begin{array}{l}0,04 \\
9\end{array}$ & $\begin{array}{l}19,8 \\
02\end{array}$ & $\begin{array}{l}13,8 \\
1\end{array}$ & $\begin{array}{l}13,0 \\
3\end{array}$ & $\begin{array}{l}19,8 \\
0\end{array}$ \\
\hline
\end{tabular}

Tabel 5.13 memperlihatkan perubahan tingkat kedalaman kemiskinan dan tingkat keparahan kemiskinan setelah distribusi ZIS. Dari tabel dapat dianalisa bahwa rumah tangga yang memiliki anggota keluarga 1-3 orang selain memiliki insiden kemiskinan tertinggi, juga memiliki tingkat kedalaman kemiskinan dan tingkat keparahan kemiskinan tertinggi. Distribusi ZIS pada kelompok ini belum mampu menurunkan insiden kemiskinan yang ada (grafik 56).

Namun demikian, dari sisi kedalaman kemiskinan, distribusi ZIS memperlihatkan kinerja positif yang cukup menggembirakan. Fakta menunjukkan bahwa baik poverty gap maupun income gap mengalami penurunan pasca ZIS masing -masing sebesar 7,92 persen. Demikian pula dengan tingkat keparahan kemiskinan setelah nilai indeks Sen dan indeks FGT pasca ZIS dapat diminimalisir masing-masing sebesar 6,74 persen dan 13,81 persen. Temuan ini mengokohkan implikasi positif program ZIS terhadap upaya pengurangan tingkat kedalaman dan keparahan kemiskinan.

Selanjutnya, kelompok responden yang kedua adalah rumah tangga mustabik yang beranggotakan 4-6 orang. Distribusi ZIS pada kelompok ini memperlihatkan dampak signifikan pada penurunan jumlah kemiskinan (poverty incidence. Pasca distribusi ZIS, insiden kemiskinan hanya turun sebesar 2,30 persen. Meski presentase penurunannya kecil, namun ini mengindikasikan bahwa jumlah kemiskinan pada kelompok ini dapat diminimalisir melalui program pendayagunaan ZIS.

Sedangkan dari sisi kedalaman kemiskinan, program ZIS memperlihatkan kinerja yang lebih baik sebagaimana diindikasikan oleh penurunan indeks poverty gap dan indeks income gap masing-masing sebesar 7,01 persen. Demikian pula dengan tingkat keparahan kemiskinan yang berhasil diminimalisir oleh ZIS. Penurunan indeks Sen dan indeks FGT masing-masing 7,77 persen dan 13,03 
persen menjadi bukti yang sangat valid dalam mempersempit jurang kemiskinan dan mengurangi tingkat keparahan kemiskinan.

Sedangkan kelompok terakhir adalah rumah tangga dengan jumlah anggota lebih dari 6 orang. Pasca distribusi ZIS, insiden kemiskinan (poverty incidence) pada kelompok ini hasilnya tetap sama dengan kondisi pra ZIS. Artinya bahwa program ZIS yang telah dilakukan belum mampu mengurangi jumlah kemiskinan yang ada. Jika dianalisa lebih jauh, kemungkinan besar OPZ terkait kurang memberi perhatian terhadap perbedaan jumlah anggota keluarga ketika akan mendistribusikan ZIS.

Namun demikian, pengaruh positif ZIS dapat dilihat dari sisi kedalaman kemiskinan dan keparahan kemiskinan. Penurunan indeks poverty gap dan income gap sebesar 14,68 persen menjadi bukti valid dampak positif ZIS dalam menekan laju kedalaman kemiskinan. Demikian pula dengan pengurangan nilai indeks Sen dan indeks FGT pasca ZIS, masing-masing sebesar 10,70 persen dan 19,80 persen.

Dari temuan fakta-fakta di atas dapat disimpulkan bahwa program pendayagunaan ZIS yang telah dilakukan belum mampu mereduksi presentase insiden kemiskinan rumah tangga (kecuali rumah tangga yang beranggotakan 46 orang). Namun, program pendayagunaan ZIS memperlihatkan kinerja positif dalam mengurangi tingkat kedalaman kemiskinan dan tingkat keparahan kemiskinan di semua kelompok ukuran rumah tangga. Penurunan terbesar terjadi pada kelompok rumah tangga yang beranggotakan lebih dari 6 orang.

Tabel 5.14 berikut memperlihatkan dampak positif ZIS dalam mempercepat proses pengentasan kemiskinan.

Tabel 5.14 Analisis Time Taken to Exit

\begin{tabular}{|l|c|c|}
\hline \multicolumn{1}{|c|}{ Ukuran Rumah Tangga } & Pra ZIS & Pasca ZIS \\
\hline 1-3 Orang & 21,5 tahun & 19 tahun \\
\hline 4-6 Orang & 13,7 tahun & 12,9 tahun \\
\hline 7 Orang atau Lebih & 9,6 tahun & 9,2 tahun \\
\hline
\end{tabular}

Dari paparan data diatas, terlihat bahwa keluarga dengan ukuran anggota yang lebih besar membutuhkan waktu lebih pendek dibanding keluarga dengan ukuran anggota yang lebih sedikit.

Waktu pengentasan di tiap kelompok tersebut dapat dipersingkat melalui program ZIS. Pada kelompok rumah tangga yang beranggotakan 1-3 orang waktu pengentasannya dapat dipercepat 2,5 tahun dari 21,5 tahun menjadi 19 tahun. Kelompok rumah tangga yang beranggotakan 4-6 orang waktu pengentasannya 
dapat dipercepat 9 bulan dari 13,7 tahun menjadi 12,9 tahun. Sedangkan pada rumah tangga yang beranggotakan lebih dari 6 orang waktu pengentasannya dapat dipercepat 5 bulan.

\section{KESIMPULAN}

Berdasarkan analisis dan pembahasan yang telah dilakukan, maka dapat diperoleh beberapa kesimpulan. Pertama, secara umum pendayagunaan ZIS oleh LAZDAI dan DPU-DT di Bandar Lampung berimplikasi positif dalam mengurangi tingkat kemiskinan rumah tangga mustahik yang meliputi jumlah kemiskinan (poverty incidence), tingkat kedalaman kemiskinan dan tingkat keparahan kemiskinan. Pasca distribusi ZIS, jumlah kemiskinan (poverty incidence) mengalami penurunan meskipun presentase penurunannya sangat kecil, yaitu 1,37 persen. Hal ini dapat dilihat dari berkurangnya nilai beadcount index dari 0,785 menjadi 0,774 setelah ZIS didistribusikan. Sedangkan dari aspek kedalaman kemiskinan, distribusi ZIS mampu mengurangi defisit pendapatan rumah tangga miskin dengan garis kemiskinan yang diindikasikan oleh penurunan nilai poverty gap dan income gap masing-masing sebesar 8,17 persen. Adapun dari sisi keparahan kemiskinan, program ZIS mampu memperbaiki distribusi pendapatan di antara rumah tangga miskin yang ditandai dengan menurunnya nilai indeks Sen dan indeks FGT masing-masing sebesar 7,76 persen dan 13,82 persen.

Kedua, Pasca distribusi ZIS, kelompok rumah tangga yang insiden kemiskinannya mengalami penurunan terbesar adalah kelompok rumah tangga dengan kepala keluarga berjenis kelamin perempuan, berstatus orang tua tunggal, berusia 45-64 tahun, berpendidikan rendah (SD), berprofesi lain-lain, dan beranggotakan 4-6 orang anggota keluarga.

Ketiga, selain mengurangi jumlah kemiskinan, tingkat kedalaman kemiskinan dan tingkat keparahan kemiskinan, pendayagunaan ZIS oleh LAZDAI dan DPU-DT di Bandar Lampung juga berimplikasi positif dalam mempersingkat waktu pengentasan kemiskinan sebesar 1,1 tahun dari 14,2 tahun menjadi 13,1 tahun.

Keempat, Kelompok rumah tangga yang mampu mempersingkat waktu pengentasan kemiskinan lebih besar melalui instrument ZIS adalah kelompok rumah tangga dengan kepala keluarga berjenis kelamin perempuan, berstatus orang tua tunggal, berusia di atas 64 tahun, tidak pernah sekolah, berprofesi sebagai ibu rumah tangga, dan beranggotakan 1-3 orang anggota keluarga.

\section{DAFTAR PUSTAKA}

\section{Al-Qur'an al-Kariim}


Abu Bakar, Taqiyuddin, Kifayatul Akhyar, Semarang: Toha Putera tt.

Amar, Syamsul.1997, Pertumbuhan Ekonomi dan Pemerataan Pendapatan: Suatu Tinjauan Empirik, Padang: Forum Pendidikan IKIP Padang, no. 1 Th.XXII 1997.

Anis, Ibrahim. 1972, al-Mu'jam al-Wasith, Mesir; Daar el-Fikr.

Beik, Irfan Syauqi \& Tiara Tsani. 2012, Menurunkan Kemiskinan Melalui Pendayagunaan Zakat, Republika, 23 Februari 2012

Beik, Irfan Syauqi. 2010, Peran Zakat Mengentaskan Kemiskinan dan Kesenjangan , Republika, 29 juli 2010.

Beik, Irfan Syauqi.2010, Tiga Dimensi Zakat, Republika, 29 Juli 2010.

BPS Kota Bandar Lampung. 2012, Kota Bandar Lampung Dalam Angka 2012, Bandar Lampung; BPS Kota Bandar Lampung.

BPS. 2011, Analisis dan Penghitungan Tingkat Kemiskinan 2011, Jakarta: BPS

BPS.2011, Data dan Informasi Kemiskinan Kabupaten/Kota 2010, Jakarta; BPS.

BPS. Berita Resmi Statistik: Pertumbuhan Ekonomi Indonesia, No.09/IX/15 Feb 2006, No.10/02/Th. X, 16 Feb 2007, No.10/02/Th. XI/15 Feb 2008, No.11/02/Th. XII, 16 Feb 2009,No.12/02/Th.XIII, 10 Feb 2010 ,No.12/02/Th. XIV, 7 Feb 2011,No.13/02/Th. XV, 6 Feb 2012

Faris, Ibnu. 1399 H/1979 M, Maqaayis al-Lughah, Daar al- Fikr.

Hafidhuddin, Didin \& Juwaini, Ahmad. 2007, Membangun Peradaban Zakat, Ciputat; IMZ, Bamuis BNI.

Hafidhuddin, Didin. 2012, Metode Penetapan Harta Objek Zakat, Republika,23 Februari 2012

Hafidhuddin, Didin.1998, Panduan Praktis Tentang Zakat, Infak dan Sedekah, Jakarta; GIP. 
Hafidhuddin, Didin. 2002, Zakat Dalam Perekonomian Modern, Jakarta; GIP.

Hafidhuddin, Didin.2007, Agar Harta Berkah dan Bertambah, Jakarta:GIP

IMZ. 2011, Bangsa Betah Miskin, Ciputat: IMZ.

IZDR 2009, Zakat dan Pembangunan: Era Baru Zakat Menuju Kesejahteraan Ummat, Ciputat; IMZ .

IZDR 2010, Menggagas arsitektur zakat indonesia: Menuju Sinergi Pemerintah dan Masyarakat Sipil Dalam Pengelolaan Zakat Nasional, Ciputat; IMZ.

IZDR 2011, Kajian Empiris Zakat Dalam pengentasan Kemiskinan, Ciputat:IMZ.

IZDR 2012, Membangun Peradaban Zakat Indonesia: Soal Kebijakan dan Hal Lain yang Belum Paripurna, Ciputat; IMZ.

Jhingan.1996, Ekonomi Pembangunan dan Perencanaan, Jakarta: PT. Raja Grafindo Persada

Jurnal Kasaba, Vol. 2,No.2, Juli 2009

Khudori, Gagal Atasi Kemiskinan, Republika, Kamis, 13 Januari 2011.

Marthon, sa'id sa'd. 1406H/1986M, Madkhol lil Fikri al-Iqtishodiy fil Islam, Beirut:Muassasah ar-Risalah.

Mubarak, Muhammad. tt, Nidzom al-Islam: al-Iqtishod Mabadi' Qowaid 'Ammah, Daar al-Fikr.

Peraturan Presiden No. 13 Th 2009 Tentang Kordinasi Penanggulangan Kemiskinan

Purnamasari, Nia. 2010, Analisis Pengaruh Pendayagunaan ZIS Terhadap Pengurangan Kemiskinan (Studi Kasus: Pusat Zakat Umat LAZ Persis Garut)", Skripsi Pada FEM IPB.

Qardhawi, Yusuf, 1393 H /1973M, Fiqh az-Zakat, Beirut: Muassasah arRisalah.

Qardhawi, Yusuf, tt, al- 'Ibadah fil Islam, Kairo; Maktabah Wahbah. 
Qurthubi.1993, al-Jaami' li Ahkam al-Quran, Beirut; Daar al-Kutub al'Ilmiyyah.

Shabuni, Muhammad Ali.1993, Shofwat at-Tafasir, Beirut; Daar al-Ihya atTurats al-'Arabiy.

Shahih Bukhari. $1422 \mathrm{H}$, tahqiq Muhammad Zuhair bi Nashir an-Nashir, Daaru Thuq an-Najah.

Shahih Muslim.tt, tahqiq Muhammad Fuad 'Abdul Baaqi, Beirut ; Daarul Ihyaa at-Turast.

Sumodiningrat, Gunawan.1999, Pemberdayaan Masyarakat dan JPS, Jakarta: PT Gramedia Pustaka Utama.

Sunan Abu Dawud.tt, tahqiq Muhammad Muhyiddin Abdil Hamid, Beirut; al muktabah al 'ashriyah.

Sunan al-Nasai. 1986, tahqiq: 'Abdul Fattah Abu Ghuddah, Halb; maktab almathbu'at al-Islamiyah.

Suryadharma, Daniel.2005, Menakar Peran Ketimpangan Dalam Penanggulangan Kemiskinan, Smeru Newsletter, No.16: Okt-Des/2005.

Tsani, Tiara. 2010, Analisis Dampak Distribusi Zakat Terhadap Tingkat Kemiskinan dan KesenjanganPendapatan (Studi Kasus Pendayagunaan Zakat Oleh BAZDA Lampung Selatan), Skripsi padaFakultas Ekonomi dan Manajemen IPB : tidak diterbitkan.

Ustaimin, Muhammad Shalih. 2010, Fatawa fi Ahkami az-Zakat, Edisi Terjemahan: Ensiklopedi Zakat,Jakarta; Pustaka as-Sunnah.

Zuhaili, Wahbah. 1989, al-Fiqh al-Islami wa Adillatuhu, Suria; Daar el-Fikr. http://lampung.bps.go.id.

http://www.anggaran.depkeu.go.id.(diakses pada 17-09-2012, pkl.10.03. WIB).

http://www.baznas.or.id/ib-peduli/ (diakses pd 17-09-2012, pk1.09.27.WIB) 